\title{
Reservoir Water Quality Assessment Based on Chemical Parameters and the Chlorophyll Dynamics in Relation to Nutrient Regime
}

\author{
Usman Atique, Kwang-Guk An* \\ Department of Bioscience and Biotechnology, Chungnam National University, Daejeon, South Korea
}

Received: 5 January 2018

Accepted: 22 February 2018

\begin{abstract}
Deteriorating water quality has become a global concern. Chungju Reservoir is the largest reservoir in South Korea. Here we describe the long-term spatiotemporal variabilities and prevailing trends in physicochemical and nutrient contributing factors using datasets of 1992-2016. Seasonal, annual, multivariate analytical techniques, and water pollution index (WPI) investigations revealed monsoon rainfall events as major influential element in fluctuating water quality. Total nitrogen (TN) and total phosphorus (TP) concentration was largely affected by the intensity of monsoon rainfall along the longitudinal gradient. Seasonal and inter-annual analyses indicated the reservoir system as being N-rich and strongly P-limited. They also indicated progressive escalation of $\mathrm{pH}$, chemical oxygen demand (COD), TN, and TP - clarifying greater industrial and agricultural runoff. The transition zone (Tz) was crucial for leaching of suspended solids pointing toward an imminent siltation problem. Mann Kendal test confirmed a significantly increasing trend in $\mathrm{pH}, \mathrm{COD}, \mathrm{TN}, \mathrm{TP}$, and ammonium. Principal component analysis disclosed that water quality deterioration cannot be ascribed to a single point source but instead diffused sources. The trophic state index exhibited deviation from larger particles to severe zooplankton grazing as an explicit sign of oligo-mesotrophic state, leading to increased Secchi disk depth. WPI categorize the chemical health status as 'good.' Overall, it could be inferred that water quality was good but may face an impending degradation plus increasing nutrients and chemical loads.
\end{abstract}

Keywords: reservoir, chemical health, monsoon rainfall, water quality, zooplankton grazing, trophic state

\section{Introduction}

During the past few decades, freshwater resources are subjugated to increasing anthropogenic activities such as the construction of reservoirs for accruing the

*e-mail:kgan@cnu.ac.kr benefits of power generation, municipal water supply for drinking and household, transportation, flood control, recreation, agriculture, fishing [1], aesthetics, raising aquatic animals, and so on. Due to natural flow manipulations coupled with intensive rainfall [2], degradation of physiochemical water quality is very recognizable [3], besides trophic disarrays such as oligotrophy due to higher water retention time and 
depletion of initially higher allochthonous nutrient contributing factors [4]. Therefore, dams and reservoirs tenaciously or inadvertently alter the downstream water quality.

Water quality is assumed as the mainstay of public interest for monitoring disease and the state of healthiness in humans and aquatic organisms [5]. Freshwater quality is reportedly deteriorating because of rapid industrialization, expanding populations, and globally increasing pressure reinforced by poor management that ultimately has led to severe environmental degradation [6-7]. Water quality status is dynamic in nature and is normally estimated by approximation, deviation, or degradation of physicochemical parameters [8], which are mainly based on factor concentrations, e.g., phosphorus and nitrogen are essential within optimal ranges but become detrimentally noxious after deviation from favorable levels. Such alterations can be used for decision-making about targeted water use, for instance drinking, industrial, agricultural, and so on. Some water quality factors (e.g., phosphorus (P) and nitrogen (N)) respond promptly to environmental changes, whereas some (e.g., salinity) can take decades [9-10].

Eutrophication in lakes and reservoirs is rapidly increasing due to excessive discharge of nutrient-rich effluents originating from industry and agriculture in basin areas [11-12]. Primary production in terms of Chl-a production is a commonly used surrogate of eutrophication that is mainly based on phosphorus and nitrogen availability [13], and Carlson [14] has developed the trophic state index (TSI) for the assessment of eutrophication that is primarily based on Chl-a level in a water body. Numerous researchers have reported dealing mainly with eutrophication issues from the USA [15], Spain [16], Canada [17], China [12], South Korea [2], New Zeeland [18], Finland [19], and Brazil [20].

Chl-a has shown a positive linear relationship with total phosphorus levels in case of phosphorus-limited water bodies, and with total nitrogen (TN) in case of nitrogen-limited aquatic systems [19, 21]. Additionally, Chl-a is also closely dependent on Secchi dish depth (SDD), which is used as a measure of light availability in the water column. Interestingly, this paradigm, however, is continuously shifting due to monsoon rainfall in Asian lentic water bodies [2, 22]. Whatever the case, higher loadings of nutrients and organic matter may have a serious effect on Chl-a production as well as the biotic communities [23-24]. Therefore, nutrient contributing factors $(\mathrm{N}, \mathrm{P})$ and organic matter loads are decisively involved in concocting reservoir water quality. Furthermore, N:P mass ratios are broadly considered as a key factor for trophic state diagnosis as well as an indication of nutrient limitation [25-26]. If the N:P ratio is higher $(>17)$, it points towards phosphorus limitation, but if it is low $(<4)$, it indicates nitrogen limitation [27].

Multivariate analytical methods are frequently used for better understanding of water quality as well as the ecological health diagnosis of underground, lentic, and lotic waters. Such techniques help interpret the multifaceted data matrices in an easier and more comprehensive manner by allowing the identification of potential sources/factors than can be held responsible for watershed impact as well as present valuable means for trustworthy water resource management and solutions to pollution [28]. Principal component analysis (PCA), cluster analysis (CA), discriminate analysis (DA), and factor analysis (FA) are reportedly used in the scientific literature because of their ability to treat larger datasets of temporal and spatial parameters obtained from various study sites [5, 29-35]. PCA and CA have proven to be very important statistical tools for determining underlying relationships among various physicochemical parameters, pollutant source identification, and grouping sites or parameters into similar clusters for better understanding $[5,28,31]$.

Chungju is an exoreic reservoir in in the northeastern South Korea and is famous for being the country's largest watershed area waterbody as well as having the second largest water storage capacity. This multipurpose manmade reservoir is predominantly dedicated to domestic water supply and flood control as well as hydroelectric power generation [36]. It is described by the titanic depth and lengthier water residence time during flood seasons and discharging water during dry periods. Owing to longer water retention time, more depth and larger surface area, Chungju is categorized more as a lake-type reservoir despite its riverlike embankments as well as long riverine zone. One of the important functions the reservoir plays is for discharging sustained water flows for significant environmental flow during the drought season for downstream water quality improvement in the river, reduced pollutant effects, and enhanced scenic amenities.

Given the grander importance of Chungju Reservoir as the hot spot of domestic water supply, hydroelectric power resource, a recreational point, and the largest waterbody of South Korea, this study was planned to assess: 1) the water quality status similarities and differences at the sampling stations, 2) seasonal and annual trends among the physiochemical quality parameters, 3) inflow and discharge dynamics, 4) nutrient and Chl-a interactions, 5) revealing the existing and future trends, and 6) the trophic status evaluation of Chungju reservoir.

\section{Materials and Methods}

\section{Watershed and Study Area}

Chungju is the largest concrete gravity dam (CGD) constructed during 1978-85 in South Korea upstream of the southern Han River system. The coordinates are $37^{\circ} 00^{\prime} 22^{\prime \prime} \mathrm{N} 127^{\circ} 59^{\prime} 33^{\prime \prime} \mathrm{E}$. The layout of the reservoir, study sites, and zones are shown in Fig. 1. Salient hydrological features and dimensions are given in Table 1. During this study, three sampling stations were selected to investigate the longitudinal gradients of the 


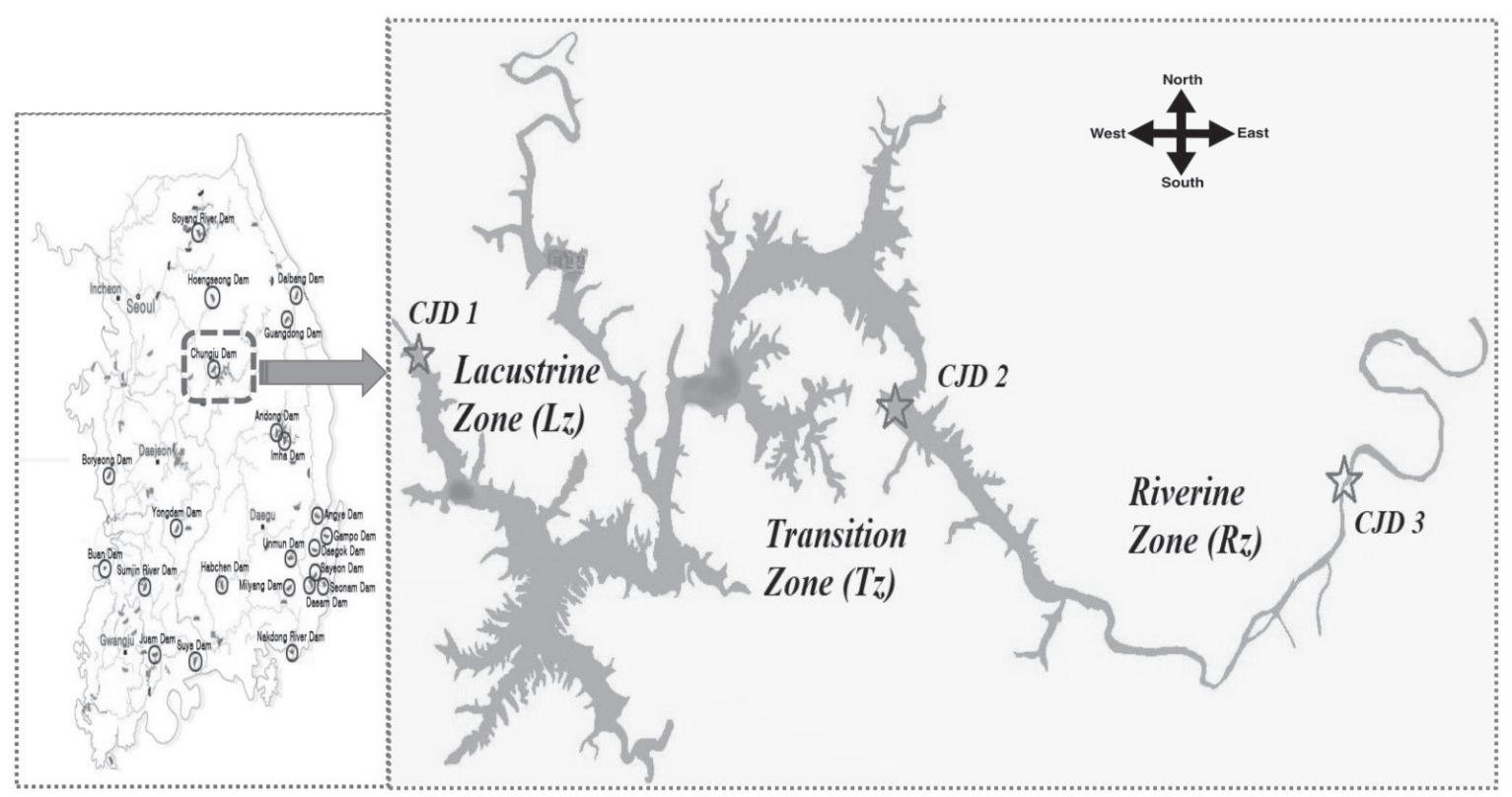

Fig. 1. The layout of Chungju dam showing its three different zones as well as the study sites.

Table 1. Salient geographic and limnological characteristics of Chungju Dam.

\begin{tabular}{|c|c|}
\hline $\begin{array}{l}\text { Hydrological and dimensional } \\
\text { attributes }\end{array}$ & Characteristics \\
\hline Construction period & $1978-1985$ \\
\hline Dam type & $\begin{array}{l}\text { Concrete gravity dam } \\
\text { (C.G.D.) }\end{array}$ \\
\hline Height of dam (m) & 97.50 \\
\hline Length of dam (m) & 447 \\
\hline Dam size & 0.902 million $\mathrm{m}^{3}$ \\
\hline Normal altitude (m) & 147.50 \\
\hline Water surface elevation (m) & 129 \\
\hline Mean depth (m) & 28.5 \\
\hline Average annual volume $\left(\mathrm{m}^{3}\right)$ & $1535 \times 10^{6}$ \\
\hline $\begin{array}{l}\text { Average water residence time } \\
\text { (days) }\end{array}$ & 102 \\
\hline Average annual rainfall (mm) & $1,197.60$ \\
\hline Flood water level (m) & 138 \\
\hline Water supply water level (m) & 84 \\
\hline Emergency water supply capacity & $496.00 \times 10^{6}$ \\
\hline Basin area $\left(\mathrm{Km}^{2}\right)$ & $6,642.00$ \\
\hline Total storage capacity $\left(\mathrm{m}^{3}\right)$ & $2,750 \times 10^{6}$ \\
\hline Active capacity $\left(\mathrm{m}^{3}\right)$ & $1,789 \times 10^{6}$ \\
\hline Effective storage $\left(\mathrm{m}^{3}\right)$ & $1,789 \times 10^{6}$ \\
\hline $\begin{array}{l}\text { Active hydroelectric power } \\
\text { generation }(\mathrm{kW})\end{array}$ & $412 \times 10^{3}$ \\
\hline Design discharge volume $\left(\mathrm{m}^{3} / \mathrm{s}\right)$ & 16,200 \\
\hline Maximum discharge quantity $\left(\mathrm{m}^{3} / \mathrm{s}\right)$ & 20850 \\
\hline
\end{tabular}

reservoir depth. The longitudinal clines were designated as three distinct zones: lacustrine $(L z)$, transition $(T z)$, and riverine $(R z)$. This total waterbody catchment area of $6642 \mathrm{~km}^{2}$ is further divided into distinct subwatersheds: 1) reservoir subwatershed $\left(498 \mathrm{~km}^{2}\right)$, 2) Han River subwatershed $\left(5484 \mathrm{~km}^{2}\right)$, 3) Jaecheon stream $\left.\left(461 \mathrm{~km}^{2}\right), 4\right)$ Gogyo streams $\left(30 \mathrm{~km}^{2}\right)$, and 5) Dongdal and Gwang streams $\left(169 \mathrm{~km}^{2}\right)$. The range of catchment area elevation is $115-1559 \mathrm{~m}$ with average hillslope of $36.9 \%$. According to the land use pattern of the watershed area, $82.3 \%\left(5469 \mathrm{~km}^{2}\right)$ is forest area and only $12.2 \%\left(811 \mathrm{~km}^{2}\right)$ is under agricultural use [37]. The datasets used in this study were obtained during 1992-2016 from the National Institute of Environmental Research (NIER).

\section{Physicochemical Water Quality Analysis}

During this study, 18 physicochemical water quality factors were measured from three sampling stations during 1992-2016. The summary statistics and detail of parameters considered during the study are specified in Table 2. $\mathrm{pH}$, dissolved oxygen, temperature, electrical conductivity, and Chl-a were recorded at the spot of monitoring stations by using the multi-parameter water quality sensors having probes dedicated for the factors (YSI Sonde 6600, Environmental monitoring system, Ohio, USA). Total coliform bacteria were measured as per the standard method opted for by APHA [38]. Total nitrogen (TN) and total dissolved nitrogen (TDN) were chemically evaluated by following the second derivative method followed by sample digestion in persulfate solution [39-40]. Ammonia nitrogen $\left(\mathrm{NH}_{4}-\mathrm{N}\right)$ and nitrate nitrogen $\left(\mathrm{NH}_{3}-\mathrm{N}\right)$ were assessed by phenate method and ion chromatography, respectively. The next step followed was the filtration of the extract from the source 
Table 2. Mean and standard deviation of water quality parameters in three zones of Chungju Dam, 1992-2016.

\begin{tabular}{|c|c|c|c|c|c|}
\hline \multirow{2}{*}{$\begin{array}{l}\text { Parameter } \\
\text { Category }\end{array}$} & \multirow{2}{*}{ Water quality parameters } & \multirow{2}{*}{$\begin{array}{l}\text { Abbreviations } \\
\text { and units }\end{array}$} & \multicolumn{3}{|c|}{ Mean \pm standard deviation (Range) } \\
\hline & & & $\mathrm{Rz}$ & $\mathrm{Tz}$ & $\mathrm{Lz}$ \\
\hline \multirow{5}{*}{ Physico-chemical } & $\mathrm{pH}$ & $\mathrm{pH}$ & $\begin{array}{c}8.09 \pm 0.41 \\
7.1-9.5\end{array}$ & $\begin{array}{c}8.00 \pm 0.44 \\
4-9.2\end{array}$ & $\begin{array}{c}7.99 \pm 0.44 \\
6.3-9.5\end{array}$ \\
\hline & Dissolved oxygen & $\mathrm{DO}\left({ }^{\circ} \mathrm{C} / \mathrm{L}\right)$ & $\begin{array}{c}10.78 \pm 2.41 \\
4-17.5\end{array}$ & $\begin{array}{c}10.24 \pm 2.29 \\
4.1-15.5\end{array}$ & $\begin{array}{l}9.14 \pm 2.67 \\
3.1-22.9\end{array}$ \\
\hline & Water temperature & $\mathrm{T}\left({ }^{\circ} \mathrm{C}\right)$ & $\begin{array}{c}14.44 \pm 7.8 \\
1-27.2\end{array}$ & $\begin{array}{c}14.14 \pm 6.95 \\
2-27.2\end{array}$ & $\begin{array}{c}13.53 \pm 6.80 \\
2-29\end{array}$ \\
\hline & Biological oxygen demand & $\mathrm{BOD}\left({ }^{\circ} \mathrm{C} / \mathrm{L}\right)$ & $\begin{array}{c}1.35 \pm 0.37 \\
0.5-2.8\end{array}$ & $\begin{array}{c}1.26 \pm 0.32 \\
0.3-2.5\end{array}$ & $\begin{array}{c}0.89 \pm 0.37 \\
0.3-2.6\end{array}$ \\
\hline & Chemical oxygen demand & $\mathrm{COD}\left({ }^{\circ} \mathrm{C} / \mathrm{L}\right)$ & $\begin{array}{c}2.18 \pm 0.43 \\
1-3.6\end{array}$ & $\begin{array}{c}2.10 \pm 0.43 \\
1-3.7\end{array}$ & $\begin{array}{c}2.19 \pm 0.51 \\
1.1-3.7\end{array}$ \\
\hline $\begin{array}{c}\text { Fecal Indicator } \\
\text { Bacteria }\end{array}$ & Total number of E. Coli & TNEC & $\begin{array}{c}43.43 \pm 188.04 \\
0-2200\end{array}$ & $\begin{array}{c}18.21 \pm 42.72 \\
0-500\end{array}$ & $\begin{array}{c}317.29 \pm 1581.48 \\
0-16917\end{array}$ \\
\hline \multirow{3}{*}{$\begin{array}{l}\text { Solids and } \\
\text { visibility }\end{array}$} & Total suspended solids & $\mathrm{TSS}\left({ }^{\circ} \mathrm{C} / \mathrm{L}\right)$ & $\begin{array}{l}5.01 \pm 6.98 \\
0.2-63.9\end{array}$ & $\begin{array}{l}3.01 \pm 3.88 \\
0.2-35.9\end{array}$ & $\begin{array}{l}2.65 \pm 5.81 \\
0.2-92.2\end{array}$ \\
\hline & Electrical conductivity & $\mathrm{EC}(\mu \mathrm{S} / \mathrm{cm})$ & $\begin{array}{c}224.75 \pm 42.39 \\
130-383\end{array}$ & $\begin{array}{c}209.82 \pm 33.61 \\
120-469\end{array}$ & $\begin{array}{c}196.16 \pm 32.64 \\
90-351\end{array}$ \\
\hline & Secchi disk depth * & $\mathrm{SDD}(\mathrm{m})$ & $\begin{array}{c}0.27 \pm 0.41 \\
-1.05-1.46\end{array}$ & $\begin{array}{c}0.46 \pm 0.37 \\
-0.79-1.46\end{array}$ & $\begin{array}{c}0.51 \pm 0.33 \\
-1.20-1.46\end{array}$ \\
\hline \multirow{9}{*}{ Nutrient regime } & Total nitrogen & $\mathrm{TN}\left({ }^{\circ} \mathrm{C} / \mathrm{L}\right)$ & $\begin{array}{l}2.38 \pm 0.57 \\
1.13-4.92\end{array}$ & $\begin{array}{l}2.29 \pm 0.53 \\
0.86-4.92\end{array}$ & $\begin{array}{l}2.35 \pm 0.69 \\
1.43-6.98\end{array}$ \\
\hline & Total phosphorus & $\mathrm{TP}(\mu \mathrm{g} / \mathrm{L})$ & $\begin{array}{c}22.85 \pm 14.08 \\
1-117\end{array}$ & $\begin{array}{c}19.49 \pm 10.63 \\
1-84\end{array}$ & $\begin{array}{c}21.78 \pm 21.89 \\
0-273\end{array}$ \\
\hline & $\begin{array}{c}\text { Total nitrogen total phosphorus } \\
\text { ratio }\end{array}$ & TN:TP ratio & $\begin{array}{c}160.09 \pm 286.34 \\
20.23-3892\end{array}$ & $\begin{array}{c}182.55 \pm 304.19 \\
35.55-4496\end{array}$ & $\begin{array}{c}179.48 \pm 373.61 \\
0-6148\end{array}$ \\
\hline & Total dissolved nitrogen & TDN (mg/L) & $\begin{array}{l}2.10 \pm 0.38 \\
1.07-3.67\end{array}$ & $\begin{array}{l}2.03 \pm 0.32 \\
1.29-3.13\end{array}$ & $\begin{array}{l}2.16 \pm 0.41 \\
1.10-4.09\end{array}$ \\
\hline & Ammonia nitrogen & $\begin{array}{l}\text { NH4-N } \\
(\mathrm{mg} / \mathrm{L})\end{array}$ & $\begin{array}{c}0.04 \pm 0.048 \\
0-0.63\end{array}$ & $\begin{array}{c}0.03 \pm 0.03 \\
0-0.16\end{array}$ & $\begin{array}{c}0.10 \pm 0.12 \\
0-0.89\end{array}$ \\
\hline & Nitrate nitrogen & $\begin{array}{l}\mathrm{NO} 3-\mathrm{N} \\
(\mathrm{mg} / \mathrm{L})\end{array}$ & $\begin{array}{l}1.87 \pm 0.57 \\
0.32-4.28\end{array}$ & $\begin{array}{l}1.82 \pm 0.53 \\
0.22-4.20\end{array}$ & $\begin{array}{l}1.69 \pm 0.49 \\
0.05-3.97\end{array}$ \\
\hline & Total dissolved phosphorus & $\mathrm{TDP}(\mu \mathrm{g} / \mathrm{L})$ & $\begin{array}{c}16.37 \pm 11.40 \\
0-94\end{array}$ & $\begin{array}{c}13.68 \pm 8.23 \\
0-44\end{array}$ & $\begin{array}{c}11.18 \pm 7.88 \\
0-47\end{array}$ \\
\hline & Phosphate phosphorus & PO4-P $(\mu \mathrm{g} / \mathrm{L})$ & $\begin{array}{c}21.02 \pm 161.58 \\
0-2264\end{array}$ & $\begin{array}{l}8.22 \pm 7.50 \\
0-74\end{array}$ & $\begin{array}{l}5.38 \pm 5.75 \\
0-49\end{array}$ \\
\hline & Chlorophyll-a & CHL-a $(\mu \mathrm{g} / \mathrm{L})$ & $\begin{array}{c}4.57 \pm 4.38 \\
0-25.2\end{array}$ & $\begin{array}{c}3.28 \pm 3.22 \\
0-31.1\end{array}$ & $\begin{array}{l}3.44 \pm 4.27 \\
0.2-28.2\end{array}$ \\
\hline
\end{tabular}

* Secchi disk depth (SDD) was calculated by using the empirical equation of SDD $=0.76-\log _{10}(\mathrm{TSS})$ [73]

sample of water through GF/C filters. The phosphorus and its allied chemical species - total phosphorus (TP), total dissolved phosphorus (TDP), and phosphate phosphorus $\left(\mathrm{PO}_{4}-\mathrm{P}\right)$ - were analyzed by the ascorbic acid method that was followed by persulfate oxidation [40-41]. Total suspended solids (TSS), biological oxygen demand (BOD), and chemical oxygen demand (COD) were analyzed according to standard methods described by [40]. Secchi disk depth (SDD) was calculated by using the empirical equation of total suspended solids (TSS), and the formula was expressed as $0.76 \times \log _{10}$ (TSS). According to standards proposed, the nutrient analyses were repeated three times for precision and the estimation of BOD, COD, and TSS was performed twice $[38,42]$.

\section{Water Pollution Index (WPI)}

Chemical health assessment was evaluated by use of a modified multi-metric model of water pollution index $\left(\mathrm{WPI}_{\mathrm{KR}}\right)$. It was adapted from nutrient pollution index (NPI) approach of the same index modified after Dodds et al. [43] in the USA and Lee and An [44] in South Korea. Basically, it consists of 07 metrics/ parameters (Table 3$)$. The WPI ${ }_{\mathrm{KR}}$ metrics $\left(\mathrm{M}_{1-7}\right)$ used for chemical water health status are $\mathrm{M}_{1}$ : total nitrogen 
$(\mathrm{mg} / \mathrm{L}) ; \mathrm{M}_{2}$ : total phosphorus $(\mu \mathrm{g} / \mathrm{L}) ; \mathrm{M}_{3}$ : ambient ratios of TN:TP; $\mathrm{M}_{4}$ : biological oxygen demand $(\mathrm{mg} / \mathrm{L})$; $\mathrm{M}_{5}$ : total suspended solids $(\mathrm{mg} / \mathrm{L}) ; \mathrm{M}_{6}$ : electrical conductivity $(\mu \mathrm{S} / \mathrm{cm})$; and $\mathrm{M}_{7}$ : Chl-a $(\mu \mathrm{g} / \mathrm{L})$. It is based on some of the crucially important parameters that have proven effective on changing water quality for longer terms. The scoring criteria ascribed to every single metric was established for limits demarcated after following the third of observed distributions of obtained values. Consequently, the entrusted scoring criteria for every metric (M) was either 5, 3, or 1 score, respectively, depending upon the role of each water quality factor on the overall chemical health status of water. Based on the obtained scores, the concluding chemical health evaluation of each sampling station was calculated next to attain the total scores by summing up all the metric scores. Finally, it led to the decisive classification of each site as excellent (Ex. 31-35), good (G. 25-29), fair (F. 19-23), poor (P. 13-17), or very poor (VP. 07-11).

\section{Trophic State Index Deviation (TSID)}

The trophic state index deviation (TSID) was calculated by using the following formulae derived from Carlson [14], and the relations are shown by the following equations:

$$
\begin{gathered}
\text { TSI }(\mathrm{TP})=14.42 \mathrm{Ln}(\mathrm{TP})+4.15 \\
\text { TSI }(\mathrm{TN})=14.43 \mathrm{Ln}(\mathrm{TN})+54.45 \\
\text { TSI }(\mathrm{SD})=-14.41 \mathrm{Ln}(\mathrm{SD})+60 \\
\text { TS I }(\mathrm{Chl})=9.81 \mathrm{Ln}(\mathrm{Chl})+30.6
\end{gathered}
$$

\section{Statistical Analysis}

The obtained datasets were subjected to multivariate data analysis techniques such as principal component analysis (PCA), cluster analysis (CA), correlational analysis, and Mann-Kendall (MK) trend test. We also analyzed the datasets for spatio-seasonal and interannual variations of selected water quality parameters. Most of the data analyses were carried out using the Sigma Plot [45] version 10 (Systat. Software Inc; USA) and PAST [46]. Means and standard deviations were calculated using the PAST software as well as it also rendered to run the $\mathrm{MK}$ trend test, $\mathrm{CA}$, and PCA.

\section{Results and Discussion}

\section{Spatio-Seasonal Trend Analysis}

Seasonal trends in water quality factors are primarily maneuvered by the precipitation patterns, and this was very evident in all the zones of Chungju Reservoir (Fig. 3, Table 2). The summer monsoon rainfall (JulyAugust) mainly influences precipitation patterns in South Korea, wherein almost $70 \%$ of rainfall occurs and shows conspicuous hydrological changes in all types of water bodies. The study of rainfall pattern and water quality factors during 1992-2016 showed diverse changes in different factors, e.g., $\mathrm{pH}$ recorded the highest in proceeding months of September and October in all the zones. The DO and WT manifested the classical inverse relationship. Since most downpour occurs during JulyAugust, therefore, monsoon precipitation was decisively influencing; otherwise, most of the physiochemical
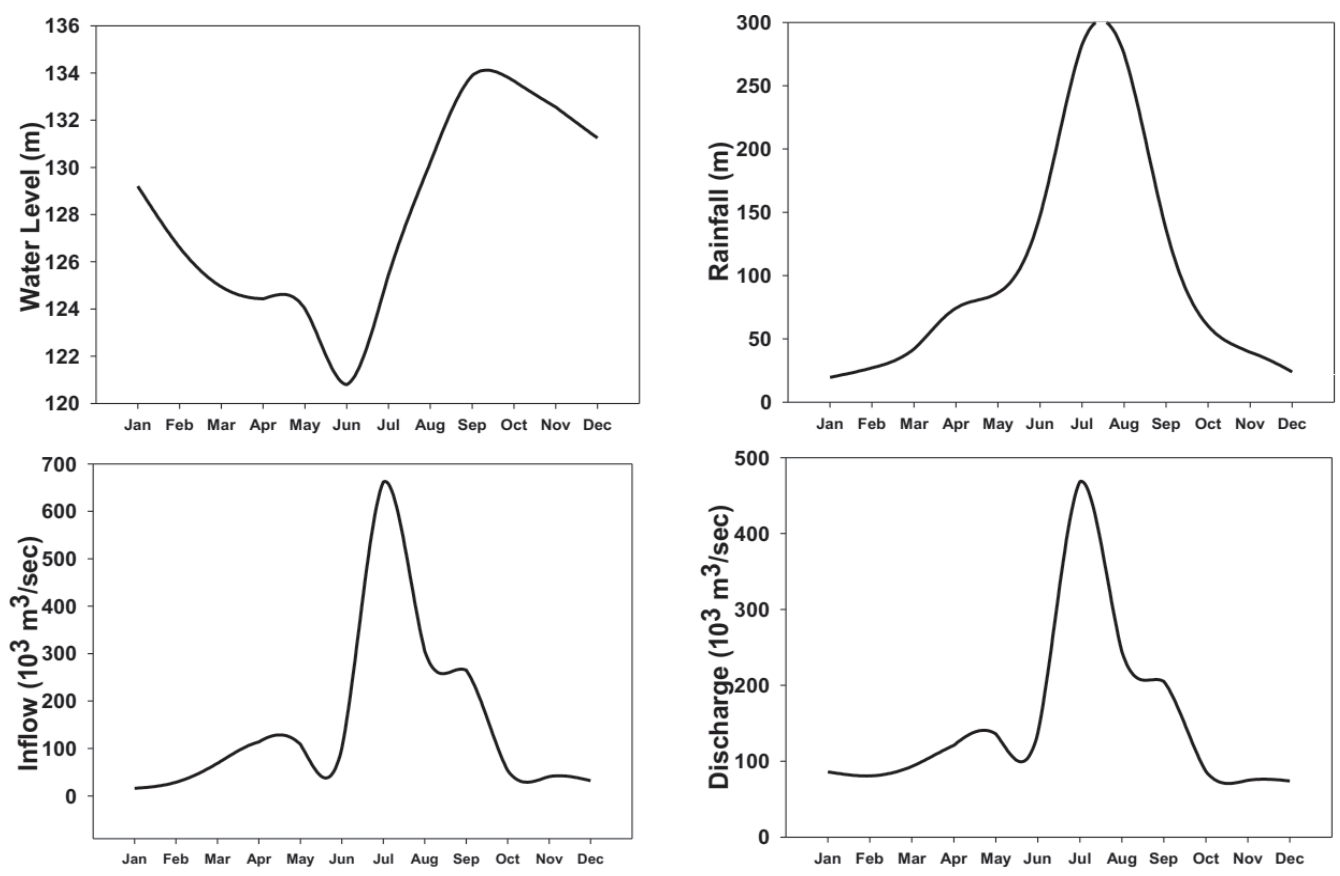

Fig. 2. Seasonal dynamics of water level, rainfall, inflow, and discharge in Chungju Reservoir, 1992-2016. 
water quality factor activities were identical. The BOD showed almost no effect of rainfall, but in $T z$ and $R z$ it was higher as compared to the $L z$. Conversely, the COD showed an unblemished increase after the monsoon period, which indicated the transport of more chemicalborne matter along with the runoff waters entering the lake environment. However, the overall COD level was well below alarming limits. TSS transport into the reservoir - especially higher in the $R z$ - implied higher siltation and it was mainly governed by the summer monsoon rainfall. The EC in $L z$ was almost similar but showed a decline in $R z$, wherein the TSS was higher.
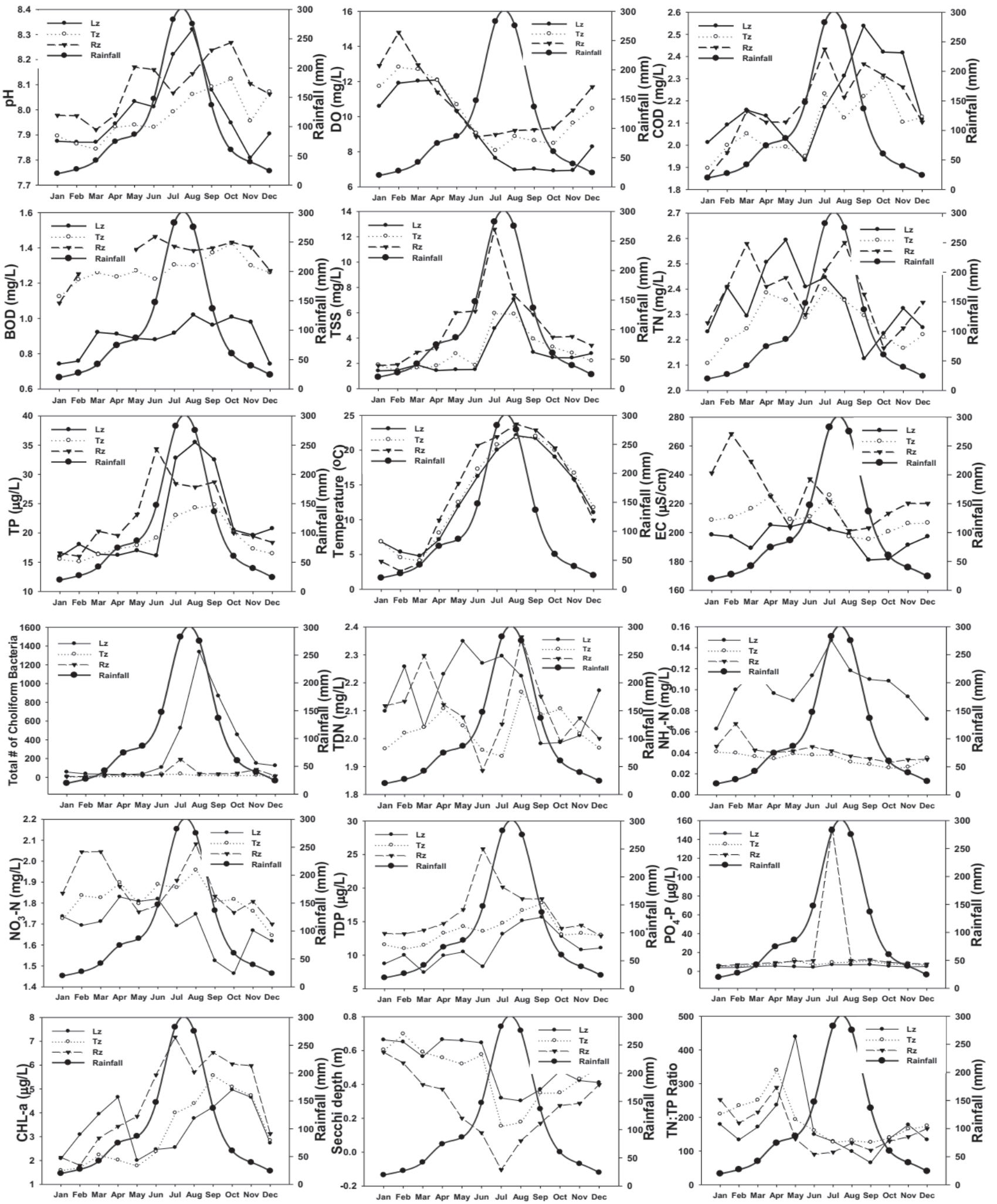

Fig. 3. Seasonal and spatial analysis of water quality parameters in $L z, T z$, and $R z$ of Chungju Reservoir, 1992-2016. 
Table 3. Chemical health assessment of Chungju Dam based on modified multi-metric water pollution index (WPI) during $1992-2016$.

\begin{tabular}{|c|c|c|c|c|c|c|c|}
\hline \multirow{2}{*}{ Category } & \multirow{2}{*}{ Model metrics (M) } & \multicolumn{3}{|c|}{ Scoring criteria } & \multicolumn{3}{|c|}{ Mean \pm standard deviation scores } \\
\hline & & 5 & 3 & 1 & $R z$ & $T z$ & $L z$ \\
\hline \multirow{3}{*}{ Nutrient Regime } & $\begin{array}{c}\mathrm{M}_{1}: \text { Total Nitrogen } \\
(\mathrm{mg} / \mathrm{L})\end{array}$ & $<1.5$ & $1.5-3.0$ & $>3$ & $\begin{array}{l}2.38 \pm 0.57 \\
(3)\end{array}$ & $\begin{array}{l}2.29 \pm 0.53 \\
(3)\end{array}$ & $\begin{array}{c}2.35 \pm 0.69 \\
(3)\end{array}$ \\
\hline & $\begin{array}{c}\mathrm{M}_{2}: \text { Total Phosphorus } \\
(\mu \mathrm{g} / \mathrm{L})\end{array}$ & $<30$ & $30-100$ & $>100$ & $\begin{array}{c}22.85 \pm 14.08 \\
(5)\end{array}$ & $\begin{array}{c}19.49 \pm 10.63 \\
(5)\end{array}$ & $\begin{array}{c}21.78 \pm 21.89 \\
(5)\end{array}$ \\
\hline & $\mathrm{M}_{3}: \mathrm{TN}$ :TP ratio & $>50$ & $20-50$ & $<20$ & $\begin{array}{c}160.09 \pm 286.34 \\
(5)\end{array}$ & $\begin{array}{c}182.55 \pm 304.19 \\
(5)\end{array}$ & $\begin{array}{c}179.48 \pm 373.61 \\
(5)\end{array}$ \\
\hline Organic Matter & $\begin{array}{l}\mathrm{M}_{4}: \text { Biological Oxygen } \\
\text { Demand }(\mathrm{mg} / \mathrm{L})\end{array}$ & $<1$ & $1-2.5$ & $>2.5$ & $\begin{array}{l}1.35 \pm 0.37 \\
\text { (3) }\end{array}$ & $\begin{array}{l}1.26 \pm 0.32 \\
\text { (3) }\end{array}$ & $\begin{array}{l}0.89 \pm 0.37 \\
(5)\end{array}$ \\
\hline \multirow{2}{*}{$\begin{array}{l}\text { Ionic Contents } \\
\text { and Solids }\end{array}$} & $\begin{array}{c}\mathrm{M}_{5}: \text { Total Suspended Solid } \\
(\mathrm{mg} / \mathrm{L})\end{array}$ & $<4$ & $4-10$ & $>10$ & $\begin{array}{l}5.01 \pm 6.98 \\
(3)\end{array}$ & $\begin{array}{l}3.01 \pm 3.88 \\
(5)\end{array}$ & $\begin{array}{l}2.65 \pm 5.81 \\
(5)\end{array}$ \\
\hline & $\begin{array}{l}\mathrm{M}_{6} \text { : Electrical Conductivity } \\
(\mu \mathrm{S} / \mathrm{cm})\end{array}$ & $<180$ & $\begin{array}{l}180- \\
300\end{array}$ & $>300$ & $\begin{array}{c}224.75 \pm 42.39 \\
(3)\end{array}$ & $\begin{array}{c}209.82 \pm 33.61 \\
(3)\end{array}$ & $\begin{array}{c}196.16 \pm 32.64 \\
(3)\end{array}$ \\
\hline \multirow[t]{3}{*}{$\begin{array}{l}\text { Primary Production } \\
\text { Indicator }\end{array}$} & $\begin{array}{c}\mathrm{M}_{7} \text { : Sestonic Chlorophyll } \\
(\mu \mathrm{g} / \mathrm{L})\end{array}$ & $<3$ & $3-10$ & $>10$ & $\begin{array}{l}4.57 \pm 4.38 \\
\text { (3) }\end{array}$ & $\begin{array}{l}3.28 \pm 3.22 \\
\text { (3) }\end{array}$ & $\begin{array}{l}3.44 \pm 4.27 \\
\text { (3) }\end{array}$ \\
\hline & $\begin{array}{c}\text { Final Scores } \\
\text { (Model Criteria of WPI) }\end{array}$ & & & & 25 & 27 & 27 \\
\hline & Water Quality Criteria & & & & Good & Good & Good \\
\hline
\end{tabular}

TNCB showed a huge variation during monsoon rainfall, especially in the $L z$ and lesser or no changes in $R z$ and $T z$. Coliform bacteria level is used as an important water quality indicator, which shows the contamination of human fecal matter [47]. The higher the TNCB, the greater the likelihood of fecal contagion, and henceforth greater threats of waterborne diseases [48]. The TN inputs in all the zones were similar until the monsoon period, and then showed a decline in the aftermath of increased rainfall. TP, however, was continuously shadowing the higher peak of monsoon rainfall that displayed that the main carrier of higher $\mathrm{P}$ loading into the reservoir was none other than the monsoon rainwater that carried most of the $\mathrm{P}$ from the catchment areas and was transported in the reservoir [49-50]. Seasonal concentrations of other nitrogen species such as TDN, $\mathrm{NH}_{4}-\mathrm{N}$, and $\mathrm{NO}_{3}-\mathrm{N}$ were different from the comportment of $\mathrm{N}$ in the three zones, e.g., TDN showed promising increments with rainfall in the $R z$, but in $L z$ it showed a peak in the preceding months of monsoon. On the other hand, $\mathrm{NO}_{3}-\mathrm{N}$ was higher during most of the months, along with monsoon in the $R z$. The values of $\mathrm{PO}_{4}-\mathrm{P}$ and TDP were almost similar in all three zones, with a difference in the levels of TDP that were diluted because of the monsoon. In approximation with TP, the sestonic Chl-a levels were also mainly influenced by the monsoon rainfall pattern in all zones, with $\mathrm{Rz}$ being the most favorite place for the favorable growth of sestonic Chl-a. It showed a conspicuous decline in the proceeding period of monsoon. The SDD was the lowest during the monsoon rainfall period. The ambient ratios of TN:TP were inversely proportional to the rainfall pattern, but still sufficiently higher.

Spatial and seasonal analysis of Cungju Reservoir revealed heterogenic variations among the water quality factors in the zones showing longitudinal modifications from headwater $(R z)$ towards the dam site $(L z)$. Chl-a and TP were higher in the riverine zone as compared to other parts, which clearly indicates higher TP loads from the inflowing currents. The longitudinal difference in the levels of nutrient contributing factors (TP, TN), resultant algal biomass in terms in Chl-a, and increased reception of solid contents as TSS has been reported in other studies [51-53]. Distinct and huge longitudinal gradient among three zones $(L z-T z-R z)$ was not, however, noticed in the case of Chungju Reservoir.

\section{Annual Trends in Water Chemistry}

The annual variations showed distinct heterogeneities in nutrient contributing factor distribution, solid content loads, COD, and Chl-a concentrations in the ambient lake environment (Fig. 4). The annual concentrations of sestonic Chl-a, TN, TP, and COD were primarily affected by the annual precipitation level in the catchment area. Based on annual precipitation rates during the study, interchangeabe flood and drought conditions prevailed, with 1998, 2003, and 2011 being the high flooding years. The rainfall pattern is such a huge influencing factor that it was strikingly played down with the annual water quality parameter trends such as during drought years, when water $\mathrm{pH}$ dropped below neutral (6.4) and vice versa (9.6). Therefore, it could be inferred that selected water quality factors changed in a synchronous manner with the flood and drought years. BOD annual variations showed asynchronous behavior with the flood, drought, and average rainfall years. On the other hand, COD showed approximating increases in levels with increasing amounts of rainfall. COD showed a gradual increase 


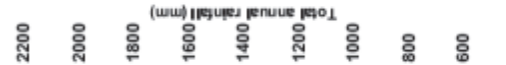

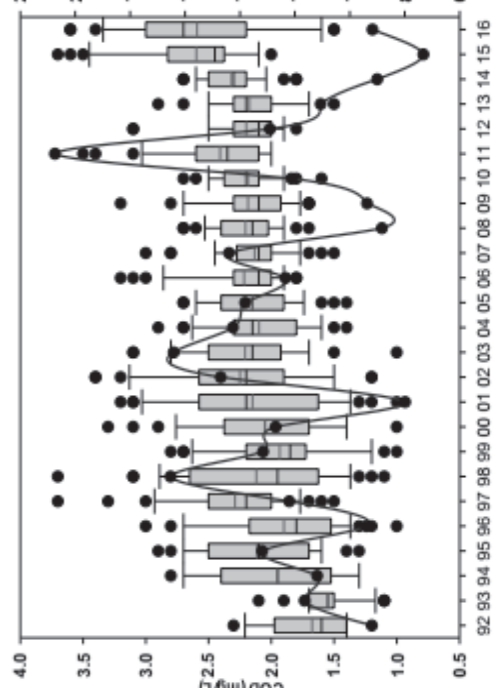

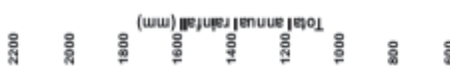

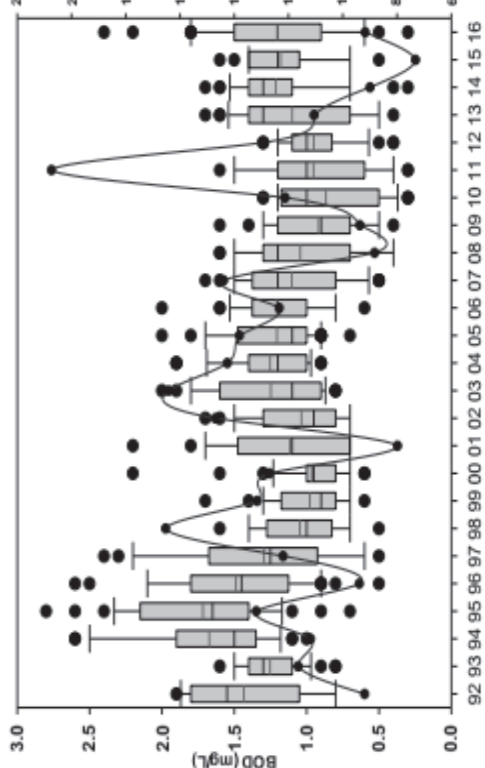

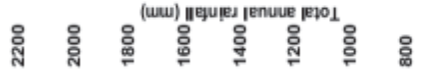

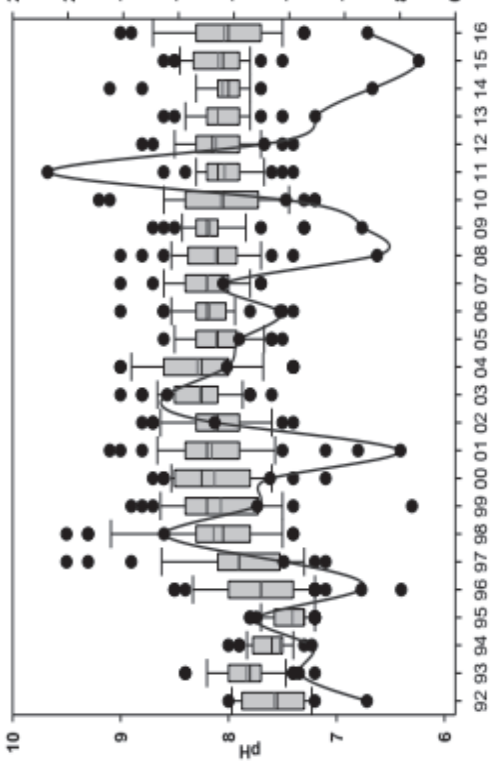

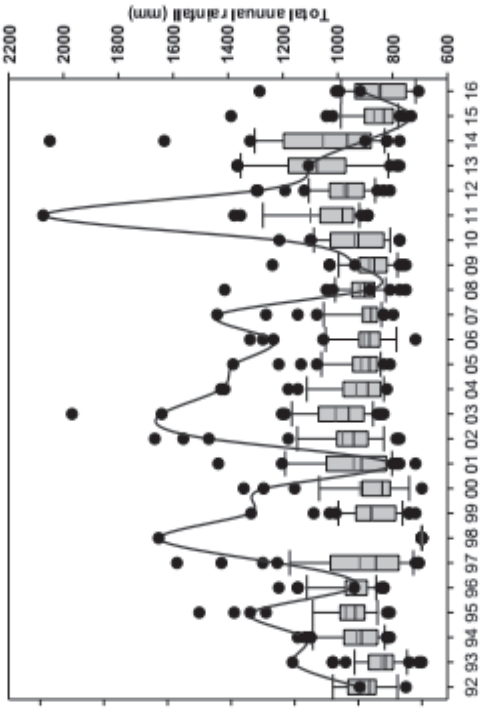

๕

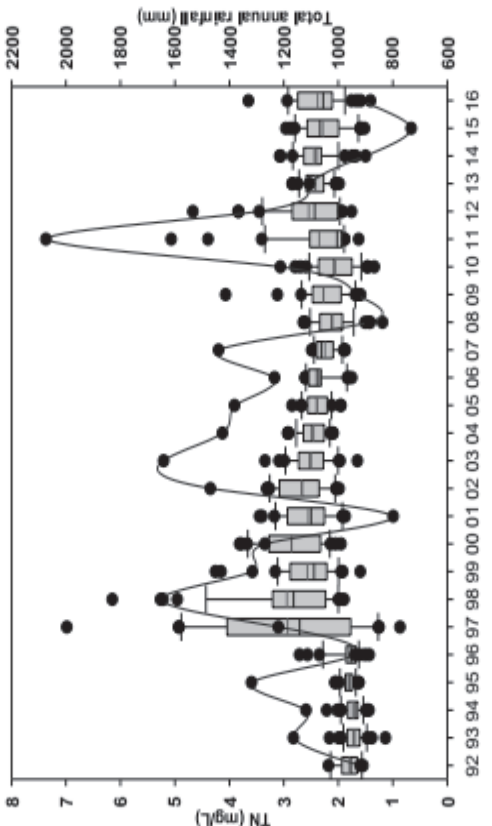

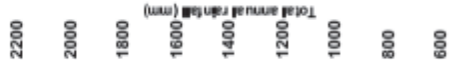

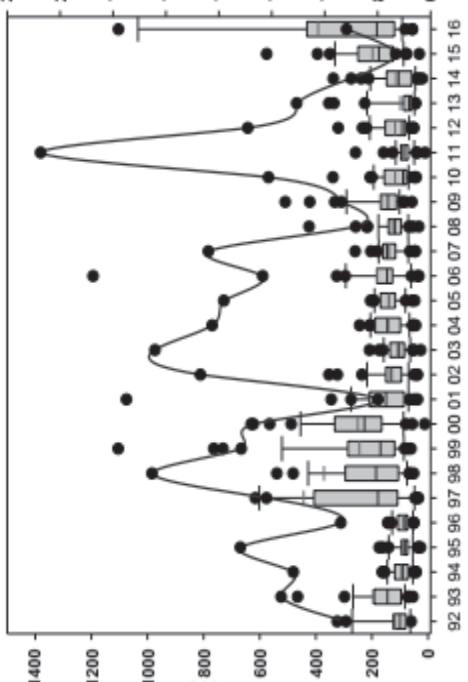

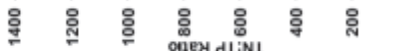

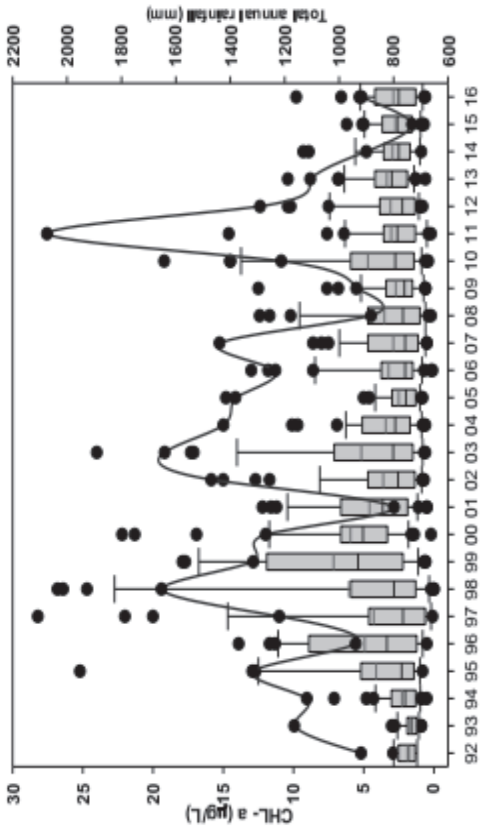

ปั่ :

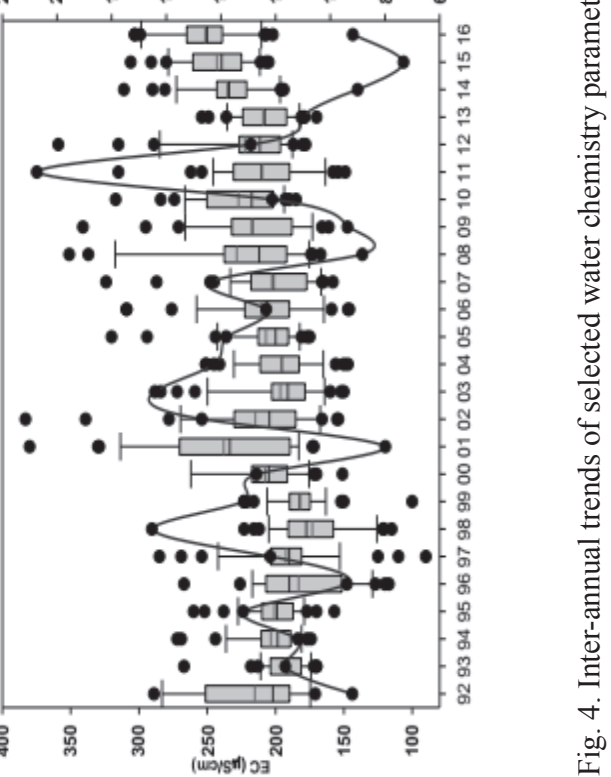




\begin{tabular}{|c|c|c|c|c|c|c|c|c|c|c|c|c|c|c|c|c|c|c|c|c|c|c|c|c|}
\hline คิ & & & & & & & & & & & & & & & & & & & & & & & & $\stackrel{8}{-}$ \\
\hline Ô & & & & & & & & & & & & & & & & & & & & & & & $\underset{-}{8}$ & $\begin{array}{l}\overline{1} \\
\\
\end{array}$ \\
\hline 台富 & & & & & & & & & & & & & & & & & & & & & & $\underset{-}{8}$ & $\begin{array}{l}\infty \\
0 \\
0 \\
i\end{array}$ & $\mid \begin{array}{l}\infty \\
0 \\
0\end{array}$ \\
\hline 寻忌 & & & & & & & & & & & & & & & & & & & & & $\stackrel{8}{8}$ & oे & Oे. & $\frac{9}{9}$ \\
\hline 灵色 & & & & & & & & & & & & & & & & & & & & $\stackrel{8}{-}$ & f̊ & तે & ô. & 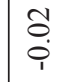 \\
\hline 㞾 & & & & & & & & & & & & & & & & & & & $\stackrel{8}{-}$ & ஜn & $\hat{\sigma}$ & oे & ప. & 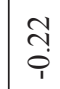 \\
\hline $\begin{array}{l}f^{\prime} \\
0^{\prime}\end{array}$ & & & & & & & & & & & & & & & & & & $\stackrel{8}{-}$ & $\stackrel{0}{0}$ & $\begin{array}{l}\hat{8} \\
\hat{i}\end{array}$ & oे & $\begin{array}{l}0 \\
0 \\
0\end{array}$ & : & 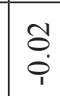 \\
\hline 官 & & & & & & & & & & & & & & & & & $\stackrel{8}{\circ}$ & $\stackrel{0}{0}$ & 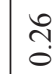 & \begin{tabular}{l}
\multirow{2}{*}{} \\
i
\end{tabular} & กี & $\begin{array}{l}7 \\
\vdots \\
i\end{array}$ & $\frac{7}{0}$ & $\begin{array}{l} \pm \\
0\end{array}$ \\
\hline $\begin{array}{l}z_{1} \\
0_{m} \\
z^{\prime}\end{array}$ & & & & & & & & & & & & & & & & $\stackrel{8}{-}$ & $\begin{array}{l}\text { ô } \\
\text { i }\end{array}$ & $\begin{array}{l}0 \\
0 \\
i\end{array}$ & $\stackrel{\overbrace{}}{0}$ & ô. & F & $\overline{0}$ & of & $\stackrel{0}{0}$ \\
\hline $\begin{array}{l}z_{1} \\
\bar{z}^{+}\end{array}$ & & & & & & & & & & & & & & & $\stackrel{8}{\circ}$ & : & $\begin{array}{l}\infty \\
0 \\
\\
1\end{array}$ & $\stackrel{\overrightarrow{0}}{\dot{0}}$ & $\stackrel{\circ}{\circ}$ & ồ & : & : & $\frac{9}{\dot{\varphi}}$ & oे \\
\hline 䏍 & & & & & & & & & & & & & & $\stackrel{8}{8}$ & $\stackrel{-}{0}$ & $\stackrel{n}{\stackrel{2}{8}}$ & 今. & $\tilde{O}$ & $\tilde{O}$ & I. & $\stackrel{I}{0}$ & $=$ & 苂 & $\begin{array}{l}0 \\
0 \\
0\end{array}$ \\
\hline 怘 & & & & & & & & & & & & & $\stackrel{8}{-}$ & $\begin{array}{l}\overrightarrow{0} \\
\dot{\varphi}\end{array}$ & $\stackrel{\infty}{\circ}$ & $\begin{array}{l}2 \\
0 \\
0\end{array}$ & 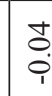 & $\begin{array}{l}\hat{8} \\
0 \\
\end{array}$ & $\stackrel{\circ}{\circ}$ & $\begin{array}{l}0 \\
0 \\
0 \\
0\end{array}$ & í. & O̊. & ț & 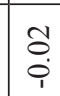 \\
\hline U & & & & & & & & & & & & 8 & $\ddot{0}$ & i & ô & $\begin{array}{l}\text { ô } \\
\text { i. }\end{array}$ & $\stackrel{2}{0}$ & $\stackrel{\overbrace{}}{0}$ & $\stackrel{\infty}{\circ}$ & oे & : & $=$ & ¿্ & $\stackrel{8}{\circ}$ \\
\hline$\mapsto$ & & & & & & & & & & $\S$ & & $\begin{array}{l}0 \\
\frac{0}{1} \\
\end{array}$ & $\hat{0}$ & ô. & 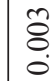 & $\begin{array}{l}2 \\
8 \\
0 \\
i\end{array}$ & $\stackrel{7}{\dddot{Z}}$ & $\stackrel{\infty}{0}$ & तิ & $\stackrel{n}{0}$ & ల్లి & 辛 & $\vec{\circ}$ & $\stackrel{m}{\mathscr{m}}$ \\
\hline $\begin{array}{l}\ddot{H} \\
\ddot{Z}\end{array}$ & & & & & & & & & $\stackrel{8}{-}$ & $\bar{z}$ & & $\begin{array}{c}6 \\
\\
\\
\end{array}$ & $\begin{array}{l}\overrightarrow{0} \\
\dot{\varphi}\end{array}$ & กี & $\begin{array}{l}\text { ㅁ } \\
\text { i }\end{array}$ & $\stackrel{0}{0}$ & $\stackrel{f}{+}$ & $\begin{array}{l}n \\
0 \\
0 \\
1\end{array}$ & $\begin{array}{l}0 \\
0 \\
0\end{array}$ & हn: & $\begin{array}{l}\infty \\
0 \\
0\end{array}$ & $\stackrel{\infty}{\infty}$ & $\stackrel{0}{i}$ & $\stackrel{8}{0}$ \\
\hline$\tilde{F}$ & & & & & & & & $\stackrel{8}{8}$ & 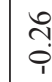 & है & & $\begin{array}{l}0 \\
\dot{c} \\
\end{array}$ & $\begin{array}{l}\widetilde{o} \\
0 \\
\\
\end{array}$ & $\stackrel{8}{\circ}$ & 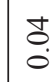 & $\begin{array}{l}\text { ô } \\
\text { is }\end{array}$ & 壳 & $\frac{0}{0}$ & $\frac{ \pm}{0}$ & $\frac{9}{0}$ & $\stackrel{7}{0}$ & ஸ̊ & ڤ̊. & $\vec{\jmath}$ \\
\hline Z & & & & & & & $\stackrel{8}{-}$ & $\stackrel{9}{\circ}$ & $\bar{g}$ & $\varepsilon$ & & $\begin{array}{c}0 \\
\\
\\
\end{array}$ & $\begin{array}{l}0 \\
\dot{0} \\
i\end{array}$ & $\stackrel{\circ}{\stackrel{0}{0}}$ & $\delta$ & $\stackrel{8}{8}$ & $\frac{m}{0}$ & $\stackrel{t}{\stackrel{0}{0}}$ & $\frac{n}{0}$ & $\stackrel{9}{6}$ & 文 & $\stackrel{\Delta}{0}$ & ঙ্ণি: & ज्ञ \\
\hline$\underset{\omega}{\tilde{\omega}}$ & & & & & & 8 & oे. & $\stackrel{\infty}{6}$ & $\stackrel{\circ}{\circ}$ & $\hat{\varepsilon}$ & & $\begin{array}{l}\infty \\
0 \\
\\
\\
\end{array}$ & $\begin{array}{l}0 \\
0 \\
0 \\
i\end{array}$ & $\stackrel{7}{0}$ & 音 & $\stackrel{ }{0}$ & $\stackrel{ \pm}{0}$ & 告 & $\stackrel{1}{0}$ & ¿̊. & $\stackrel{ }{0}$ & $\stackrel{\infty}{\circ}$ & $\stackrel{0}{0}$ & : \\
\hline ชิ & & & & & & $\stackrel{3}{=}$ & $\frac{n}{0}$ & กี่ & : & $=$ & 8 & : & $\begin{array}{l}\dot{0} \\
0\end{array}$ & $\stackrel{\infty}{\circ}$ & 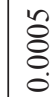 & $\begin{array}{l}0 \\
\stackrel{8}{0} \\
0 \\
0\end{array}$ & $=$ & 音 & ฮี & $\stackrel{\infty}{0}$ & $\stackrel{\infty}{0}$ & ố & $\stackrel{F}{\circ}$ & 茫 \\
\hline Оิ & & & $\S$ & 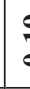 & & $\underset{0}{\infty}$ & ָָ & $\stackrel{2}{0}$ & $\bar{i}$ & $\bar{J}$ & & $\begin{array}{l}0 \\
0 \\
\end{array}$ & $\begin{array}{l}1 \\
0 \\
0 \\
i\end{array}$ & $\stackrel{0}{0}$ & $\frac{9}{9}$ & in & $\stackrel{\Xi}{\Xi}$ & ô. & $\stackrel{5}{0}$ & ڤ̊. & 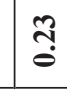 & F & $\stackrel{\infty}{\stackrel{\infty}{0}}$ & $\begin{array}{l}\text { ஸ̂. } \\
\text { î }\end{array}$ \\
\hline ̊ & & $\stackrel{8}{-}$ & 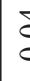 & 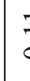 & & $\begin{array}{l}\bar{E} \\
\vdots \\
\end{array}$ & $\stackrel{0}{0}$ & 章 & $\stackrel{\infty}{\circ}$ & 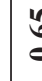 & $\S$ & हై & $\begin{array}{l} \pm \\
\dot{\varphi}\end{array}$ & $\stackrel{\circ}{\circ}$ & $\stackrel{7}{9}$ & $=$ & oे & 官 & $\frac{\Delta}{\dot{c}}$ & ô. & $\stackrel{0}{0}$ & $\stackrel{\Delta}{0}$ & $\stackrel{\overbrace{}}{0}$ & $\stackrel{\infty}{0}$ \\
\hline 壳 & $\underset{-}{8}$ & $\stackrel{\circ}{\circ}$ & $\bar{z}$ & . & & ?. & ঙ્ષ & $\stackrel{8}{\circ}$ & $\begin{array}{l}\text { oे } \\
\text { ¿ }\end{array}$ & 2 & 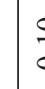 & $\frac{0}{0}$ & $\begin{array}{l}\dot{0} \\
0\end{array}$ & 웅 & $\begin{array}{l}1 \\
\stackrel{1}{0}\end{array}$ & $=$ & : & $\stackrel{2}{0}$ & $\frac{9}{9}$ & $\stackrel{0}{0}$ & $\stackrel{2}{0}$ & $\begin{array}{l}8 \\
\stackrel{0}{0}\end{array}$ & $\stackrel{\overbrace{}}{0}$ & $\begin{array}{l}0 \\
0 \\
\dot{1}\end{array}$ \\
\hline 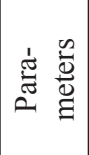 & $\frac{T}{2}$ & § & 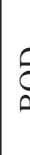 & 8 & & $\hat{\Omega}$ & Z & $\tilde{F}$ & 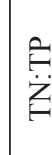 & $\mathrm{r}$ & 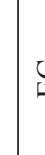 & u & 密 & 号 & $\begin{array}{l}z \\
\overline{1} \\
\mathbf{z} \\
\mathbf{z}\end{array}$ & $\begin{array}{l}z \\
0 \\
z\end{array}$ & 官 & $\begin{array}{l}1 \\
0 \\
0\end{array}$ & 营 & 芦 & 学 & 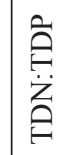 & 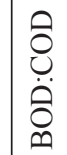 & $\begin{array}{l}\widehat{\text { g }} \\
\text { की }\end{array}$ \\
\hline
\end{tabular}




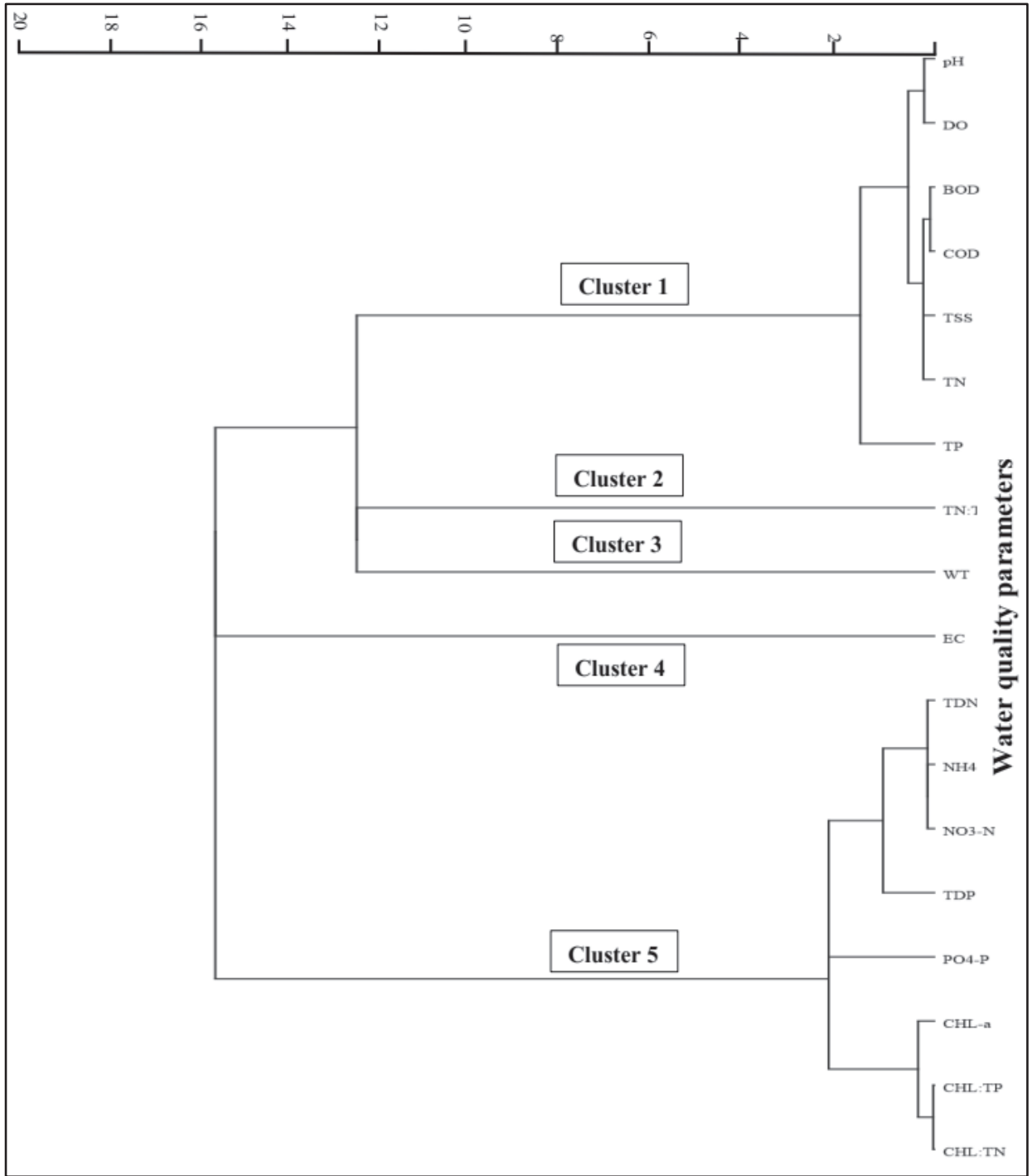

Fig. 5. Dendrogram showing the hierarchical cluster analysis of selected water quality parameters of Chungju Reservoir, $1992-2016$.

during the study period 1992-2016. The TSS loads provided insight into the collective and individual maximum rainfall events that are evident of higher TSS loads occasionally. TN and allied nitrogen species manifested annual patterns in relation to the rainfall, e.g., during dry years of 1992-96 it showed no distinct changes, but with increasing rainfall the TN loads also increased and annual means concentration of $\mathrm{TN}$ remained $>2.0 \mathrm{mg} / \mathrm{L}$. The rainfall significantly influences TP, and Chl-a showed a similar annual trend. It also showed that seasonal and annual increases in TP loads are mainly contributed to the agricultural activities that are being transported into the reservoir due to rainfall events. Annual values of ambient TN:TP ratios were decreased during the flood years, which shows that the reservoir was diluted by higher rainfall events. This type of inter-annual variation of $\mathrm{pH}$, nutrients, and sestonic Chl-a disclosed how rainfall patterns maneuver water quality and transport the effects of intensive agricultural and industrial activities in the watershed areas [2, 53-56].

\section{Reservoir Inflow and Discharge Patterns}

The seasonal and long-term patterns of flow regime were mainly defined by the Asian monsoon patterns in the catchment area (Fig. 2). Summer monsoon season (July-August) is the period of highest rainfall events, wherein $44.5 \mathrm{~mm}$ occurred during July and $35.2 \mathrm{~mm}$ during August. This monsoon rainfall amount was $37 \%$ of the total annual rainfall (inclusive of drought and flood years), which evidently proves massive precipitation during these two months. On the contrary, the lowest rainfall was observed during the winter season (December-January), with 4.53 and $4.52 \mathrm{~mm}$, respectively. In exoreic reservoirs, rainfall volume determines the inflow and discharge dynamics. During 1992-2016, the mean water level reached its lowest $(120.79 \mathrm{~m})$ before the beginning of monsoon rainfall in order to store maximum inflowing water to mitigate floods and, as a result, the postmonsoon mean water level in September reached $133.88 \mathrm{~m}$. 
Table 5. Mann-Kendall trend test on Chungju Reservoir water parameters showing trends, 1992-2016.

\begin{tabular}{|c|c|c|c|c|c|}
\hline Parameter category & Water quality parameters & S value & $\mathrm{Z}$ value & $P$ value & Trend \\
\hline \multirow{6}{*}{ Physico-chemical } & $\mathrm{pH}$ & 67848 & 7.92 & 2.31 & Significantly increasing \\
\hline & DO & 37007 & 4.31 & 1.65 & Significantly increasing \\
\hline & $\mathrm{T}$ & 7262 & 0.84 & 0.39 & No trend \\
\hline & Total \# of Coliform Bacteria & -92353 & 10.77 & 4.85 & Significantly decreasing \\
\hline & BOD & -51941 & 6.11 & 1.06 & Significantly decreasing \\
\hline & COD & 95558 & 11.16 & 6.75 & Significantly increasing \\
\hline \multirow{3}{*}{ Solids and visibility } & TSS & -21818 & 2.54 & 0.01 & Significantly decreasing \\
\hline & EC & 104439 & 12.16 & 5.19 & Significantly increasing \\
\hline & $\mathrm{SD}(\mathrm{m})$ & 21818 & 2.54 & 0.01 & Significantly increasing \\
\hline \multirow{9}{*}{ Nutrient regime } & $\mathrm{TN}$ & 51054 & 5.94 & 2.8 & Significantly increasing \\
\hline & ТP & 27316 & 3.18 & 0.0014 & Significantly increasing \\
\hline & TN:TP & -3847 & 0.45 & 0.65 & No trend \\
\hline & TDN & -7531 & 1.93 & 0.053 & No trend \\
\hline & NH4-N & 16997 & 2.39 & 0.017 & Significantly increasing \\
\hline & NO3-N & -34544 & 4.85 & 1.21 & Significantly decreasing \\
\hline & TDP & 546 & 0.139 & 0.89 & No trend \\
\hline & PO4-P & -5949 & 1.24 & 0.22 & No trend \\
\hline & CHL-a & 3508 & 0.41 & 0.68 & No trend \\
\hline \multirow{4}{*}{ Ratios } & CHL:TP & -10960 & 1.28 & 0.20 & No trend \\
\hline & CHL:TN & -17339 & 2.16 & 0.031 & Significantly decreasing \\
\hline & TDN:TDP & -5096 & 1.3 & 0.19 & No trend \\
\hline & BOD:COD & -116915 & 13.68 & 1.27 & Significantly decreasing \\
\hline
\end{tabular}

In approximation with seasonal rainfall events, the lowest inflow was observed during January and February, i.e., $16.02 \times 10^{3} \mathrm{~m}^{3} / \mathrm{sec}$ and $28.86 \times 10^{3} \mathrm{~m}^{3} / \mathrm{sec}$, respectively, whereas the highest inflow occurred during monsoon season (July-August), i.e., $661.99 \times 10^{3} \mathrm{~m}^{3} / \mathrm{sec}$ and $305.44 \times 10^{3} \mathrm{~m}^{3} / \mathrm{sec}$, respectively. The discharge dynamics were also mainly determined by the seasonal rainfall patterns and were lowest in November and December, i.e., $74.96 \times 10^{3} \mathrm{~m}^{3} / \mathrm{sec}$ and $73.89 \times 10^{3} \mathrm{~m}^{3} / \mathrm{sec}$, respectively, whereas the highest was recorded during July and August as $468.34 \times 10^{3} \mathrm{~m}^{3} / \mathrm{sec}$ and $244.42 \times 10^{3} \mathrm{~m}^{3} / \mathrm{sec}$, respectively. This observation indicated that the inflow and discharge dynamics of exoreic reservoirs are directly regulated by the seasonal rainfall events. It also indicates the success of Chungju Reservoir in mitigating the impending flood events in the locality.

\section{Health Assessment by Water Pollution Index (WPI)}

Modified multi-metric water pollution index $\left(\mathrm{WPI}_{\mathrm{KR}}\right.$ ) was used for diagnosing chemical health status
(Table 3). Comprised of 07 metrics $\left(M_{1}-M_{7}\right)$, it included the most influential water quality factors which, if shifted in a disparaging way, could act as pollutants. The four most important groups are namely nutrient regime (TN, TP, and TN:TP), organic matter (BOD or COD), solid and ionic levels (TSS and EC), and primary productivity indication (Chl-a). The chemical concentration criteria of $\mathrm{TN}$ was set as oligotrophic (3.0 mg/L), mesotrophic (1.5-3.0 mg/L), and eutrophic $(>3.0 \mathrm{mg} / \mathrm{L})$. All three zones fell under the category of mesotrophic, with $R z$ showing the higher TN influx. In the same fashion, the TP criteria were oligotrophic $(<30 \mu \mathrm{g} / \mathrm{L})$, mesotrophic $(30-100 \mu \mathrm{g} / \mathrm{L})$, and eutrophic $(>100 \mu \mathrm{g} / \mathrm{L}$. All zones $(R z, T z$, and $L z)$ were under the oligotrophic category. Ambient water TN:TP ratios also displayed oligotrophic conditions at all the stations. The mean concentrations of sestonic Chl-a also approximated with the concentrations of TN, TP, and TN:TP ratios by confirming that $R z, T z$, and $L z$ were in the oligotrophic state. The mean BOD level was maximum in $R z(1.35 \mathrm{mg} / \mathrm{L})$ and minimum at $L z(0.89 \mathrm{mg} / \mathrm{L})$. The solid content loads showed that means TSS was the highest in 
$R z(5.01 \mathrm{mg} / \mathrm{L})$ and lowest in $L z(2.65 \mathrm{mg} / \mathrm{L})$, whereas EC was observed $<180 \mu \mathrm{S} / \mathrm{cm}$ at all the longitudinal. The obtained scores after the sum of all metrics led us to categorize the chemical health status of all the zones of the reservoir as good (Rz: 25, good; Tz: 27, good; $L z: 27$, good) (Table 3). It also endorses that the sedimentation process in $\mathrm{Rz}$ may decrease the storage capacity as well as the gravitational flow of inflowing water as well as a great sink of nutrients. In the case of lakes and reservoirs, major nutrients (i.e., TN, TP, and ambient water TN:TP ratios) are identified as the vital elements liable for controlling water health and eutrophication status [46]. Previous researchers showed that higher ambient water TN:TP ratios are an indirect indicator of some nutrient limitations for Chl-a productions [51-58], and if TN:TP ratios are lower, they indicate increased nutrient pollutants leading to eutrophic conditions [43]. This sort of quality deterioration in chemical health is sumptuously supported by earlier researchers [53-54, 56-58, 59-61].

\section{Pearson Correlation Analysis}

The Pearson correlation indicated the absence of a strongly positive or significant correlation (above 0.7 ) among the majority of water quality parameters of Chungju Reservoir (Table 4). However, it has been shown that moderate and weak significant correlation exists among the various water quality factors. TN showed a weak positive correlation $(\mathrm{r}=0.31, \mathrm{P}>0.01)$, with TN:TP ratio and week negative correlation among TP and TN:TP ratios $(r=-0.26, P>0.01)$. Chl-a showed weak positive correlation with $\mathrm{TN}$ and $\mathrm{TP}(\mathrm{r}=0.15$, $\mathrm{r}=0.14, \mathrm{P}>0.01$ ), respectively. Also, Chl-a was weakly positively correlated with TDP $(\mathrm{r}=0.26, \mathrm{P}>0.01)$ as compared to $\mathrm{PO}_{4}-\mathrm{P}, \mathrm{TP}$, or $\mathrm{TN}$, and allied chemical species. Among the ambient water ratios of TDN:TDP and TN:TP, weak positive correlation $(\mathrm{r}=0.38, \mathrm{P}>0.01)$ was observed, which could be used to infer that the ambient ratios did not play a significant role in Chl-a productivity. TP showed a strong positive correlation with TDP ( $\mathrm{r}=0.74, \mathrm{P}>0.01)$, whereas $\mathrm{TN}$ showed a strong positive correlation with TDN ( $\mathrm{r}=0.86, \mathrm{P}>0.01)$, pointing toward the derivation of $\mathrm{TP}$ and $\mathrm{TN}$ by these allied chemical species. As anticipated, the negative correlation of DO with numerous other water quality parameters revealed the organic pollution persistence in Chungju reservoir that can be reflected as one of the main roots of chemical, ecological, and environmental degradation.

\section{Trend Analysis Using the Mann-Kendall (MK) Trend Test}

The Mann-Kendall (MK) statistical test is a nonparametric trend analysis method that has been widely used for trend detection in hydrological time series datasets. It is an effective tool for water resource planning and management, since it can extract useful information on the possibility of change in the tendency of water quality variables in the future. The significance of trends in water quality parameters of Chungju gave powerful insight to the existing and future trends in key regulatory factors such as TN, TP, Chl-a, BOD, COD, EC, TSS, and ambient ratios of nutrient contributing factors with Chl-a (Table 5). In the present study, $\mathrm{pH}, \mathrm{DO}, \mathrm{COD}, \mathrm{TN}, \mathrm{TP}, \mathrm{EC}, \mathrm{NH}_{4}-\mathrm{N}$, and SDD are significantly increasing in the ambient water. On the other hand, $\mathrm{BOD}, \mathrm{TSS}, \mathrm{TNCB}, \mathrm{NO}_{3}-\mathrm{N}$, CHL:TN ratios, and BOD:COD ratios are observed to be significantly decreasing. WT, ambient water TN:TP ratios, TDN, TDP, $\mathrm{PO}_{4}-\mathrm{P}, \mathrm{Chl}-\mathrm{a}$, and CHL:TP ratios showed no significant trend. Thus it was inferred that nutrient contributing factors such as TN and TP were significantly increasing, whereas Chl-a showed no significant trend, implying that TN or TP are present in a state that is not supporting future eutrophication events. It is also supported by the decreasing trend in TSS and SDD. However, COD is observed to be increasing along with $\mathrm{pH}$, which indicates increasing inflow of industrial and agricultural runoff. This test, therefore, stresses the efficient management of the catchment areas for better management of Chungju reservoir. It must be noted that trend analysis shown by the MK trend test does not necessarily imply the trend to be sustainable in the future as it mainly depends on the magnitude of variables used as well as the catchment system, which may face certain modifications due to anthropogenic activities [62-64].

\section{Hierarchical Cluster Analysis (HCA)}

We used HCA to show the sampled water quality factors with similar characteristics in Chungju to check the main sources attributed toward the parameters. Hierarchical agglomerative clustering technique is one of the most commonly used approaches to understanding the instinctive similarity relations between anyone variable with the entire dataset, and displays the results in the form of a tree diagram (a dendrogram) that depicts the proximity of variables to one another by reducing the dimensionality [65]. For clustering of water quality parameters, hierarchical agglomerated CA was carried out by using Ward's technique with squared Euclidean distance similarity measures [66]. The HCA yielded the water quality factors into five distinct clusters, with EC, WT, and TN:TP ratios acting as singular factors comprising distinct clusters (Fig. 5). In cluster 1, $\mathrm{pH}$ and DO showed similarity to one sub-cluster, indicating generic or mixed origin from the watershed. Similarly, in cluster 1, BOD, COD, TSS, and TN showed similarity rendering the observation that they were mainly contributed to by the industrial activities pointing toward the increased anthropogenic activities in the catchment areas. It also indicated the runoff waters transporting the pollutants into the reservoir. However, TP is part of cluster 1, performed differently and indicating that it mainly originated from the 
agricultural activities due to its allied chemical species along with contributions from industrial activities. In the case of clusters 2, 3, and 4, the TN:TP ratios, WT, and EC were observed to cluster singularly, showing that these factors were not affected by one source but can be attributed to generic origins, which may be either anthropogenic, industrial, or agricultural in nature. In cluster 5, TDN, $\mathrm{NH}_{4}-\mathrm{N}$, and $\mathrm{NO}_{3}-\mathrm{N}$ appeared to be clustered as in sub-cluster 1, whereas CHL-a, CHL:TP ratios, and CHL:TN ratios were yielded to sub-cluster 2. However, $\mathrm{PO}_{4}-\mathrm{P}$ was observed to act independently next to TDP, which again indicates the origin of phosphorus and allied species mainly from the agricultural sources, although not limited to a single source. Moreover, it was confirmed that for Chl-a production, TP is the limiting factor that gives insight into a gradual increase with the advancing years.

\section{Principal Component Analysis (PCA)}

Considering the complexity of the relationship between several water quality factors, it was inevitable to extract the confidential information and understanding of data structures of complex datasets without the use of principal component analysis (PCA). The principal components (PC) helped to classify the water quality factor loadings as strong, moderate, or weak in correspondence to their absolute loading strengths of $>0.75,0.75-0.50$, and $0.50-0.30$, respectively [67-68]. The detailed two-dimensional analysis of water quality parameters (Fig. 6) and correlation matrix of chemical components showed a diverse variance (Table 6). The first 07 components of PCA analysis showed $70.45 \%$ of the total variance in the Chungju water quality datasets. The first PC was mainly comprised of Chl-a and solids, which showed $15.89 \%$ variance. It also indicated that chances of eutrophication are far less during the premonsoon months, and that higher suspended solids loadings would give rise to siltation problem in the future due to increasing SDD visibility that is directly related with higher solids settlement in the lake. It also showed that the solids and chemicals being transported to the reservoirs were mainly carried along with the non-point sources such as runoff, and that a negative relationship between the DO and temperature showed the seasonal changes in the study area. The second PC showed that BOD and related chemical pollutants are decreasing, which indicates lower organic pollution, and it also showed an equilibrium among the nutrient component factors in terms of TN:TP ratios. It also showed that biological pollutants are mainly being contributed by anthropogenic activities. The third components mainly explained the nutrient contributing factors and showed that TP is acting as limiting factor. However, lower variance rules out the chances of eutrophication events in future due to the nutrients. These nutrient-contributing factors are mainly due to agricultural activities such as fertilizers and livestock production $[60,69]$. It successfully explains the existing balance between the nutrient contributing factors as well as the Chl-a production during the whole year. The fourth component explains the industrial pollutants, which are in the mild strength, but it also implies that with the continuous addition of industrial effluents, it will keep on increasing the chemical loads, which is also indicative of increasing COD and $\mathrm{pH}$ in the ambient lake environment. In the seventh $\mathrm{PC}$, moderate positive loading of TNCB indicates untreated or uncontrolled

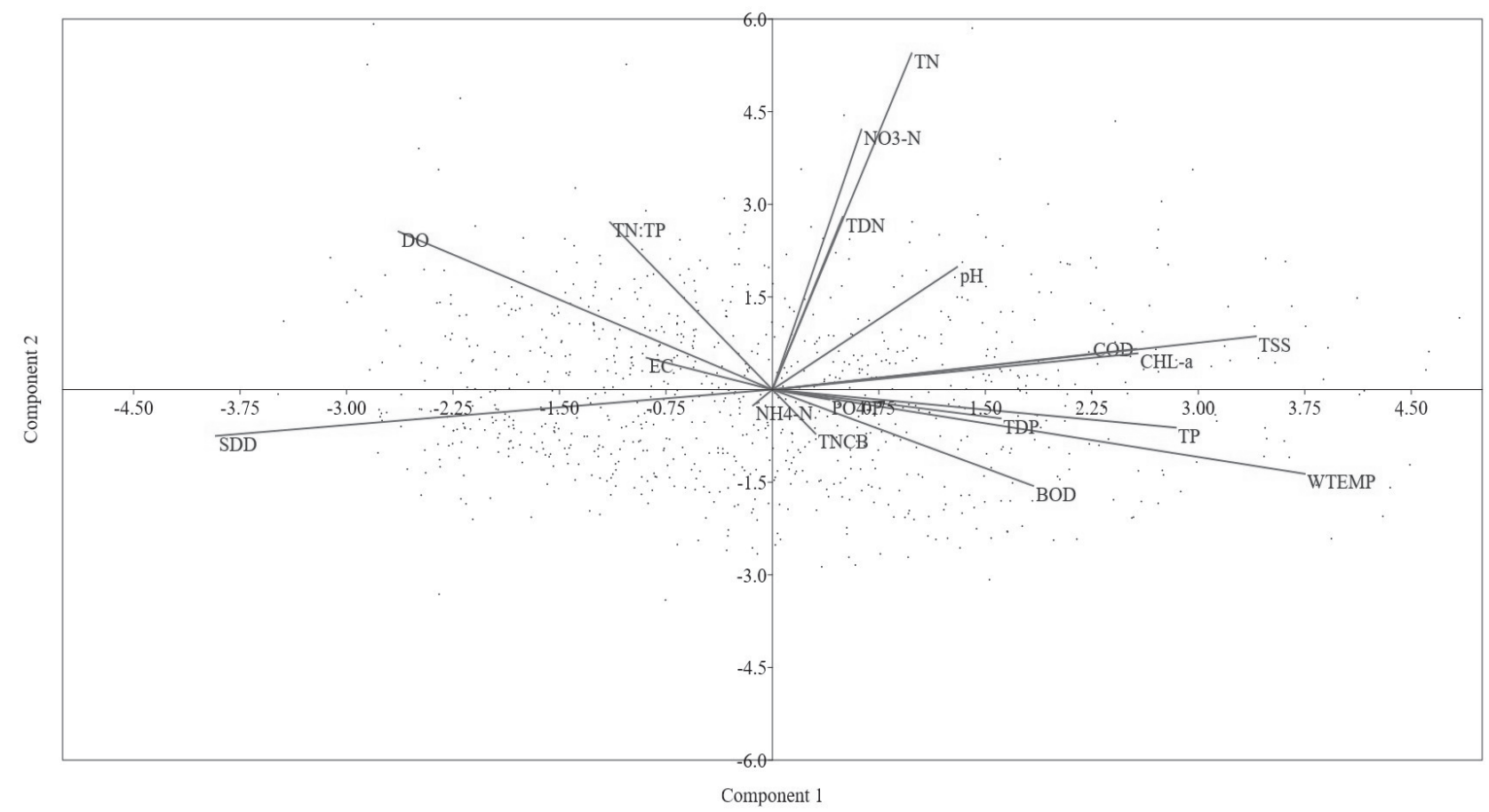

Fig. 6. Principal component analysis of Chungju Reservoir, 1992-2016. 
Table 6. Principal components, their loading values, eigenvalues, and percent variance.

\begin{tabular}{|c|c|c|c|c|c|c|c|}
\hline Variables & PC 1 & PC 2 & PC 3 & PC 4 & PC 5 & PC 6 & PC 7 \\
\hline $\mathrm{pH}$ & 0.25 & 0.38 & -0.13 & -0.08 & 0.28 & -0.20 & 0.23 \\
\hline $\mathrm{DO}(\mathrm{mg} / \mathrm{L})$ & -0.44 & 0.15 & 0.20 & 0.43 & 0.57 & -0.03 & -0.17 \\
\hline $\mathrm{BOD}(\mathrm{mg} / \mathrm{L})$ & 0.39 & -0.58 & 0.30 & 0.41 & 0.06 & -0.11 & 0.24 \\
\hline $\mathrm{COD}(\mathrm{mg} / \mathrm{L})$ & 0.43 & 0.24 & -0.28 & -0.07 & 0.26 & -0.38 & -0.05 \\
\hline $\mathrm{TSS}(\mathrm{mg} / \mathrm{L})$ & 0.51 & -0.08 & -0.31 & 0.43 & -0.16 & -0.29 & -0.39 \\
\hline $\mathrm{TN}(\mathrm{mg} / \mathrm{L})$ & 0.12 & 0.69 & -0.22 & 0.40 & -0.03 & 0.26 & 0.19 \\
\hline $\mathrm{TP}(\mu \mathrm{g} / \mathrm{L})$ & 0.42 & -0.14 & -0.50 & -0.09 & 0.29 & 0.39 & -0.01 \\
\hline TN:TP ratio & -0.12 & 0.50 & 0.38 & 0.18 & -0.36 & -0.08 & -0.07 \\
\hline Water Temp $\left({ }^{\circ} \mathrm{C}\right)$ & 0.65 & -0.07 & -0.22 & -0.26 & -0.34 & 0.02 & 0.24 \\
\hline Conductivity $(\mu \mathrm{S} / \mathrm{cm})$ & -0.17 & 0.02 & -0.01 & 0.08 & 0.50 & -0.46 & 0.34 \\
\hline Total No. of E. Coli Bacteria & 0.00 & -0.02 & -0.16 & -0.17 & -0.23 & -0.35 & 0.54 \\
\hline TDN (mg/L) & 0.05 & 0.30 & -0.16 & 0.46 & -0.12 & 0.26 & 0.26 \\
\hline $\mathrm{NH}_{4}-\mathrm{N}(\mathrm{mg} / \mathrm{L})$ & -0.06 & 0.12 & -0.18 & -0.27 & -0.23 & 0.05 & 0.02 \\
\hline $\mathrm{NO}_{3}-\mathrm{N}(\mathrm{mg} / \mathrm{L})$ & 0.04 & 0.38 & -0.19 & 0.56 & -0.06 & 0.24 & 0.30 \\
\hline $\mathrm{TDP}(\mu \mathrm{g} / \mathrm{L})$ & 0.35 & -0.20 & -0.25 & 0.01 & 0.30 & 0.46 & 0.02 \\
\hline $\mathrm{PO}_{4}-\mathrm{P}(\mu \mathrm{g} / \mathrm{L})$ & 0.10 & -0.05 & -0.01 & -0.01 & 0.10 & 0.15 & 0.09 \\
\hline Chlorophyll-a $(\mu \mathrm{g} / \mathrm{L})$ & 0.75 & 0.24 & 0.44 & -0.15 & 0.22 & 0.13 & 0.02 \\
\hline CHL:TP ratio & 0.34 & 0.48 & 0.64 & -0.04 & -0.15 & -0.02 & -0.05 \\
\hline CHL:TN ratio & 0.72 & 0.07 & 0.48 & -0.24 & 0.24 & 0.06 & -0.02 \\
\hline TDN:TDP ratio & -0.18 & 0.19 & 0.17 & 0.06 & -0.18 & -0.27 & 0.05 \\
\hline BOD:COD ratio & 0.10 & -0.69 & 0.43 & 0.42 & -0.12 & 0.14 & 0.25 \\
\hline $\mathrm{SDD}(\mathrm{m})$ & -0.63 & 0.10 & 0.26 & -0.42 & 0.16 & 0.30 & 0.25 \\
\hline Eigenvalue & 3.21 & 2.34 & 2.06 & 1.75 & 1.44 & 1.24 & 1.06 \\
\hline$\%$ Variance & 15.89 & 11.59 & 10.20 & 8.64 & 7.11 & 6.11 & 5.22 \\
\hline Cumulative $\%$ Variance & 15.89 & 27.47 & 43.36 & 52.00 & 59.11 & 65.22 & 70.45 \\
\hline
\end{tabular}

release of domestic and livestock effluents mixed with the ambient water, which can be ascribed to the municipal sewage as well as WWTPs. The fifth, sixth, and seventh PCs explained the data sets as $7.11 \%, 6.11 \%$, and $5.22 \%$, respectively, which showed that chemical and nutrient pollution events would not be severed if they occur but only if the existing set of conditions prevails [70-71].

\section{Trophic State Index Deviation (TSID)}

The seasonal and spatial TSID assessment displayed that there was huge zooplankton grazing during a whole year at all the sampling stations of Chungju Reservoir (Fig. 7). However, in premonsoon and monsoon periods, the infinitesimal presence of larger particles along with blue-green algae production was observed. However, $L z$ and $R z$ were shown to harbor the larger particles and blue-green algae, whereas the $T z$ was the main site for zooplankton grazing. TSID is a multidimensional phenomenon, which largely puts forth that no single nutrient factor can sufficiently be credited to measure the trophic state [14]. According to grazing theory, algal biomass will decrease and transparency will increase, which will lead to greater light penetration. This is also suggested that $\mathrm{P}$ is not the decisive factor in this condition. Even if the grazers regenerate the P, TSID will remain unchanged and is evidently supported in the present study in case of the spatial and seasonal trophic status of Chungju Reservoir. There is evidence that the transition from turbid state to grazing state was largely influenced by Daphnia, which resulted in the deviation from the upper right component to lower right component [11]. However, in some cases, even if TP is pronouncedly reduced, the Chl-a is lowered [72-74]. This is also attributed to zooplankton grazing, which again confirms that not a single nutrient can be responsible for the eutrophication of Chl-a production [75-78]. However, 

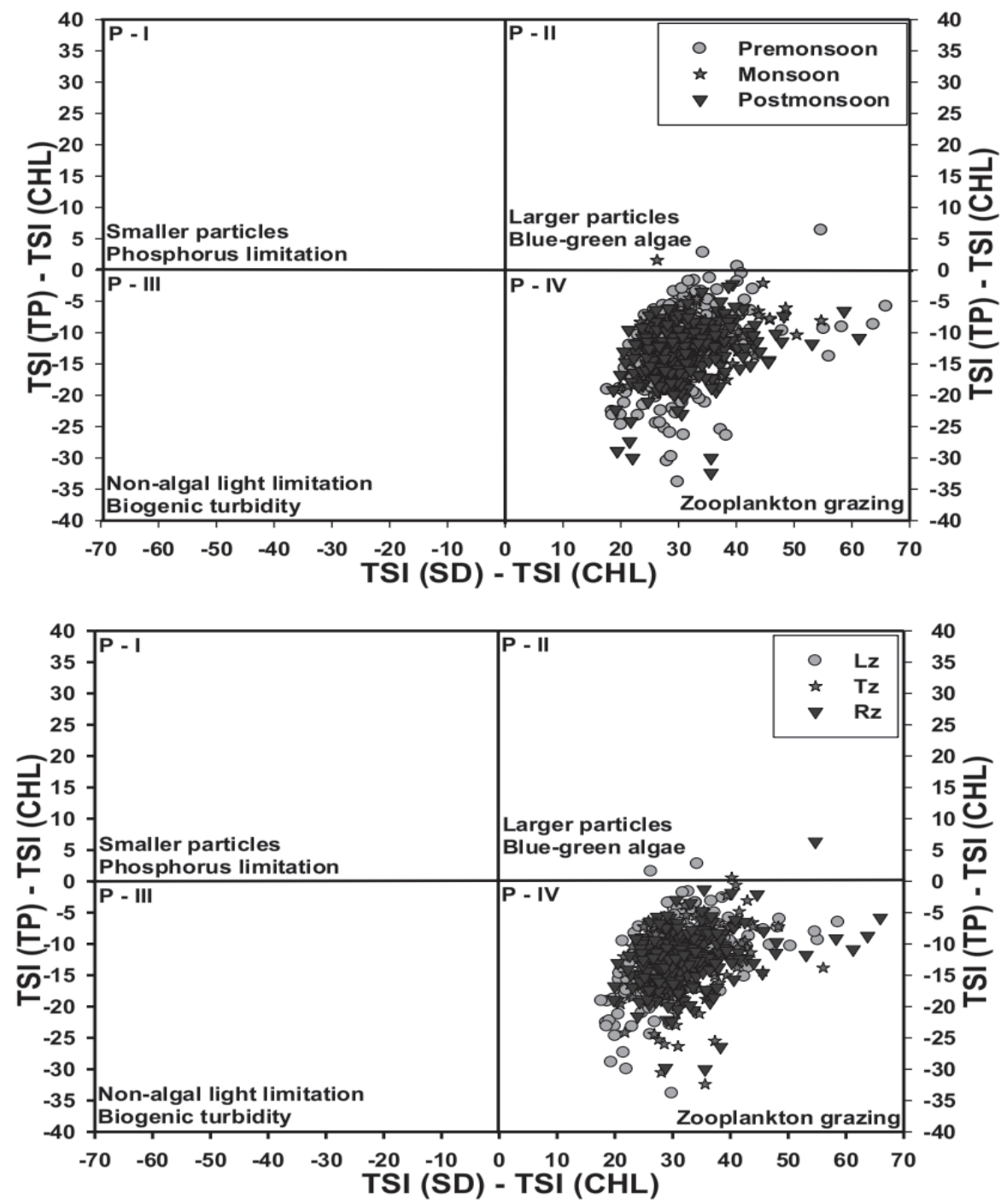

Fig. 7. Trophic state index deviation (TSID) during premonsoon, monsoon, postmonsoon (a), and $L z, T z$, and $R z$ (b) in Chungju Reservoir, 1992-2016.

in order to reveal an under-the-carpet situation, bioassays are required to be conducted to estimate the precise condition. These study results are different from the previous results, wherein it was shown as algal turbidity [74]. Algae production may be ascribed to nonalgal light attenuation, which was mainly influenced by the suspended solids. The increase in SDD is also an indication of zooplankton grazing in all the zones of the reservoir. However, most of the Korean reservoirs have shown non-algal turbidity [2], which might have been the case in the beginning, but later on the trophic status shifted toward the lower component, i.e., zooplankton grazing.

\section{Conclusion}

This study was performed to estimate water quality status of the largest freshwater reservoir in South Korea by using some multivariate analytical techniques. Our study confirmed that the overall water quality of Chungju Reservoir was in a good state, and it was confirmed by the application of WPI and shown that chemical pollutants mixed with agricultural runoff as well as domestic sewage originating from the municipality and WWTPs are gradually degrading overall quality. Based on seasonal and annual analyses, a strongly influential factor on water quality alteration was the monsoon rainfall, which is also the main culprit for the transport of chemicals and nutrient contributing factors into the reservoir from a plethora of sources such as domestic sewage, WWTPs, industrial effluents, livestock, and crop production activities. Furthermore, the reservoir was receiving an increased amount of suspended solids and these solids are settling, which may cause a siltation problem leading to decreased water storage capacity of the country's largest water reservoir. The Mann-Kendall test showed that $\mathrm{pH}, \mathrm{COD}, \mathrm{TN}, \mathrm{TP}, \mathrm{NH}_{4}-\mathrm{N}$, and $\mathrm{NO}_{3}-\mathrm{N}$ were gradually increasing in the reservoir, implying an impending nutrient-rich environment detrimental 
to the biological component of the reservoir. But the chances of eutrophication were diminutive, although with occasional blooms in the postmonsoon season due to the huge transport of nutrients. The PCA and CA provided useful insight to the complex datasets by showing that overall water quality deterioration could be ascribed to the non-point source pollutants originating mainly from the domestic and agricultural runoff from the catchment area. Moreover, the results given by CA were confirmed by PCA results. Such a big amount of pollutants is originating from such diffuse sources as domestic and agricultural runoff and hence is uncontrollable in many countries [79-80]. This study persuasively contributes in assessing and predicting the water quality dynamics - especially chemical and nutrient inputs, giving valuable insight into the chemical health status of the reservoir. Since the reservoir is very crucial for domestic water supply, integrated monitoring and control strategies for anthropogenic activities, which are never limited to agriculture and industry, is required to continuously monitor environmental degradation, and people should be encouraged to play their role in maintaining the water quality status for a sustainable water supply.

\section{Acknowledgements}

This research was supported by Daejeon Green Environment Center under the Research Development Pogram (Year 2017). Therefore, the authors would like to acknowledge the institution for financial assistance.

\section{Conflict of Interest}

The authors declare no conflict of interest.

\section{References}

1. VOGL A.L., LOPES V.L. Impacts of water resources development on flow regimes in the Brazos River. Environmental Monitoring and Assessment 157, 331, 2009. http://dx.doi.org/10.1007/s10661-008-0538-5

2. AN K.G., PARK S.S. Influence of seasonal monsoon on the trophic state deviation in an Asian reservoir. Water Air Soil Pollution 145, 267, 2003.

3. JACKSON D.C., MARMULLA G. The influence of dams on river fisheries. In: Marmulla, G., (Ed.), Dams, Fish and Fisheries: Opportunities, Challenges and Conflict Resolution. FAO Fisheries Technical Paper. No. 419. Rome. 2001.

4. MENG J., YU Z., MIAO M., KONG Q., ZHANG Y., LIU J. Differentiated Responses of Plankton and Zoobenthos to Water Quality Based on Annual and Seasonal Analysis in a Freshwater Lake. Polish Journal of Environmental Studies, 26 (2), 755, 2017. doi:10.15244/pjoes/66713

5. KAZI T.G., ARAIN M.B., JAMALI M.K., JALBANI N., AFRIDI H.I., SARFRAZ R.A., BAIG J.A., SHAH A.Q. Assessment of water quality of polluted lake using multivariate statistical techniques: A case study. Ecotoxicology and Environmental Safety 72 (2), 301, 2009 doi:10.1016/j.ecoenv.2008.02.024

6. SHARMA R.K., YADAV M., GUPTA R. Water Quality and Sustainability in India: Challenges and Opportunities. Chemistry and Water: The Science Behind Sustaining the World's Most Crucial Resource. Elsevier Inc. 2016. doi:10.1016/B978-0-12-809330-6.00005-2

7. IQBAL S., ATIQUE U., MUGHAL M.S., KHAN N., HAIDER M.S., IQBAL K.J., AKMAL M. Effect of Selenium Incorporated in Feed on the Hematological Profile of Tilapia, Journal of Aquaculture Research and Development. 8 (9), 2017. doi:10.4172/2155-9546.1000513

8. LOGAN B., TAFFS K. Relationship between diatoms and water quality (TN, TP) in sub-tropical east Australian estuaries. Journal of Paleolimnology. 50, 123, 2013.

9. ARORA M., CASAS-MULET R., COSTELLOE J.F., PETERSON T.J., MCCLUSKEY A.H., STEWARDSON M.J. Impacts of Hydrological Alterations on Water Quality. Water for the Environment: From Policy and Science to Implementation and Management. Elsevier Inc. 2017. doi:10.1016/B978-0-12-803907-6.00006-1

10. GONG D., GAO X., NTAKIRUTIMANA T., GUO J., LI K. Water quality status along the Liangtan River and control planning alternatives for pollution reduction. Pol. J. Environ. Stud. 22 (4), 1061, 2013.

11. CARLSON R.E., HAVENS K.E. Simple Graphical Methods for the Interpretation of Relationships between Trophic State Variables, Lake and Reservoir Management, 21 (1), 107, 2005. DOI: 10.1080/07438140509354418

12. GUO J., ZHANG C., ZHENG G., XUE J., ZHANG L. The establishment of season-specific eutrophication assessment standards for a water-supply reservoir located in Northeast China based on chlorophyll-a levels. Ecological Indicators, 85, 11,. 2018 doi:10.1016/J.ECOLIND.2017.09.056

13. PARK Y., CHO K.H., PARK J., CHA S.M., KIM J.H. Development of early-warning protocol for predicting chlorophyll-a concentration using machine learning models in freshwater and estuarine reservoirs, Korea. Science of The Total Environment, 502, 31, 2015 doi:10.1016/j.scitotenv.2014.09.005

14. CARLSON R.E. A trophic state index for lakes. Limnology and Oceanography, 22 (2), 361, 1977. doi:10.4319/ 10.1977.22.2.0361

15. ALAM R.Q., BENSON B.C., VISSER J.M., GANG D.D. Response of estuarine phytoplankton to nutrient and spatio-temporal pattern of physico-chemical water quality parameters in Little Vermilion Bay, Louisiana. Ecological Informatics, 32, 79, 2016 doi:10.1016/j. ecoinf.2016.01.003

16. ÁlVAREZ X., VALERO E., SANTOS R.M.B., VARANDAS S.G.P., SANCHES FERNANDES L.F., PACHECO F.A.L. Anthropogenic nutrients and eutrophication in multiple land use watersheds: Best management practices and policies for the protection of water resources. Land Use Policy, 69, 1, 2017. doi:10.1016/j. landusepol.2017.08.028

17. ZHANG W., RAO Y.R. Application of a eutrophication model for assessing water quality in Lake Winnipeg. Journal of Great Lakes Research, 38, 158,. 2012 doi:10.1016/j.jglr.2011.01.003

18. ABELL J.M., ÖZKUNDAKCI D., HAMILTON D., MILLER S. Relationships between land use and nitrogen and phosphorus in New Zealand lakes. Marine and Freshwater Research, 62 (2), 162, 2011. doi: 10.1071/ MF10180 
19. EKHOLM P., MITIKKA S. Agricultural lakes in Finland: Current water quality and trends. Environmental Monitoring and Assessment, 116 (1-3), 111, 2006. doi:10.1007/s10661-006-7231-3

20. SILVINO R.F., BARBOSA F. Eutrophication potential of lakes: an integrated analysis of trophic state, morphometry, land occupation, and land use. Brazilian journal of biology = Revista brasleira de biologia, 75 (3), 607, 2015. doi:10.1590/1519-6984.18913

21. CARLSON R.E. Expanding the Trophic State Concept to Identify Non-Nutrient Limited Lakes and Reservoirs. Proceedings of a National Conference on Enhancing the States' Lake Management Programs, 59, 1991.

22. HAN J.H., KIM B., KIM C., AN K.G. Ecosystem health evaluation of agricultural reservoirs using multi-metric lentic ecosystem health assessment (LEHA) model. Paddy and Water Environment, 12 (1), 7, 2014. doi:10.1007/ s10333-014-0444-0

23. FREY J.W., BELL A.H., HAMBROOK BERKMAN J.A, LORENZ D.L. Assessment of Nutrient Enrichment by Use of Algal- , Invertebrate- , and Fish-Community Attributes in Wadeable Streams in Ecoregions surrounding the Great Lakes. U.S. Geological Survey Scientific Investigations Report. 2011-5009, 49, 2011.

24. SCHINDLER D.W. The dilemma of controlling cultural eutrophication of lakes. Proc R Soc B Biol Sci. 279, 4322, 2012. doi:10.1098/rspb.2012.1032

25. AN K.G., CHOI J.W., LEE Y.J. Modifications of ecological trophic structures on chemical gradients in lotic ecosystems and their relations to stream ecosystem health. Animal Cells and Systems, 17 (1), 53, 2013. doi:10.1080/19 768354.2013.768295

26. SEITZINGER S.P., LEE R.Y. Land-based nutrient loading to LMEs: a global watershed perspective on magnitudes and sources. Environ. Dev. 17, 220, 2016.

27. DODDS W.K. Eutrophication and trophic state in rivers and streams. Limnology and Oceanography, 51, 671, 2006. doi:10.4319/1o.2006.51.1_part 2.0671

28. JUNG K.Y., LEE K.L., IM T.H., LEE I.J., KIM S., HAN K.Y., AHN J.M. Evaluation of water quality for the Nakdong River watershed using multivariate analysis. Environmental Technology \& Innovation, 5, 67, 2016. doi:10.1016/j.eti.2015.12.001

29. KöSE E., TOKATLI C., ÇIÇEK A. Monitoring stream water quality: a statistical evaluation. Pol. J. Environ. Stud. 23 (5), 1637, 2014.

30. ATIQUE U., AN K.-G. Stream Health Evaluation Using a Combined Approach of Multi-Metric Chemical Pollution and Biological Integrity Models. Water, 10, 661, 2018.

31. BARAKAT A., EL-BAGHDADI M., RAIS J., AGHEZZAF B., SLASSI M. Assessment of spatial and seasonal water quality variation of Oum Er Rbia River (Morocco) using multivariate statistical techniques. International Soil and Water Conservation Research, 4 (4), 284, 2016. doi:10.1016/j.iswcr.2016.11.002

32. SHARMA M., KANSAL A., JAIN S., SHARMA P. Application of multivariate statistical techniques in determining the spatial temporal water quality variation of Ganga and Yamuna Rivers present in Uttarakhand State, India. Water Quality, Exposure and Health, 7 (4), 567, 2015.

33. PHUNG D., HUANG C., RUTHERFORD S., DWIRAHMADI F., CHU C., WANG X., DINH T.A. Temporal and spatial assessment of river surface water quality using multivariate statistical techniques: A study in Can Tho City, a Mekong Delta area, Vietnam. Environmental Monitoring and Assessment, 187 (5), 1, 2015.

34. KUMARASAMY P., JAMES R.A., DAHMS H.U., BYEON C.W., RAMESH R. Multivariate water quality assessment from the Tamiraparani river basin, Southern India. Environmental Earth Sciences, 71 (5), 2441, 2014.

35. THUONG N.T., YONEDA M., MATSUI Y. Does embankment improve quality of a river? A case study in To Lich River inner city Hanoi, with special reference to heavy metals. Journal of Environmental Protection, 4 (4), 361, 2013.

36. CHOI C., AHN J., YI J. Flood mitigation analysis for abnormal flood. WIT Transactions on Ecology and the Environment, 133, 107, 2010. doi:10.2495/FRIAR100101

37. PARK J.Y., KIM S.J. Potential impacts of climate change on the reliability of water and hydropower supply from a multipurpose dam in South Korea. Journal of the American Water Resources Association, 50 (5), 1273, 2014. doi:10.1111/jawr.12190

38. APHA. Standard Methods for the Examination of Water and Wastewater, 21st ed.; American Public Health Association: New York, NY, USA. 2005.

39. CRUMPTON W.G., ISENHART T.M. MITCHELL P.D. Nitrate and organic $\mathrm{N}$ analyses with second-derivative spectroscopy. Limnol. Oceanogr. 37, 907, 1992.

40. EATON A.D. FRANSON M.A.H. Standard Methods for the Examination of Water and Wastewater, (Eds.), American Public Health Association, Washington, D.C. 2005.

41. PREPAS E.E. RIGLER F.A. Improvements in qualifying the phosphorus concentration in lake water. Can. J. Fish. Aquat. Sci. 39, 822, 1982

42. MOE. Standard methods for the examination of water quality contamination, 7th edn., Gwacheon, Korea, 435, 2000 [In Korean].

43. DODDS W.K., JONES J.R. WELCH E.B. Suggested classification of stream trophic state: Distributions of temperate stream types by chlorophyll, total nitrogen and phosphorus. Water Res. 32, 1455, 1998.

44. LEE H.J. AN K.G. The Development and Application of Multi-metric Water Quality Assessment Model for Reservoir Managements in Korea. Korean J. Limnol. 42, 242, 2009.

45. SIGMA PLOT version 10, Systat Software, Inc., San Jose California USA, www.systatsoftware.com

46. PAST. 3.15, The Past of the Future. Oyvind Hammer, Natural History Museum, University of Oslo.

47. DĄBROWSKA J., BAWIEC A., PAWĘSKA K., KAMIŃSKA J., STODOLAK R. Assessing the Impact of Wastewater Effluent Diversion on Water Quality. Polish Journal of Environmental Studies, 26 (1), 9, 2017. doi:10.15244/pjoes/64748

48. SOOD A., SINGH K.D., PANDEY P. SHARMA S. Assessment of bacterial indicators and physicochemical parameters to investigate pollution status of Gangetic river system of Uttarakhand (India). Ecol Indic. 8 (5), 709, 2008. doi:10.1016/j.ecolind..01.001.

49. GAO L., LI D.J., ZHANG Y.W. Nutrients and particulate organic matter discharged bythe Changjiang (Yangtze River): seasonal variations and temporal trends. J. Geophys.Res. Biogeosci. 117:G04001. 2015. http://dx.doi. org/10.1029/2012JG001952

50. HAN C., ZHENG B., QIN Y., MA Y., YANG C., LIU Z., CAO W., CHI M. Impact of upstream river inputs and reservoir operation on phosphorus fractions 
in water-particulate phases in the Three Gorges Reservoir. Science of The Total Environment, 610-611, 1546, 2018. doi:10.1016/J.SCITOTENV.2017.06.109

51. LEE Y., KIM J.K., JUNG S., EUM J., KIM C., KIM B. Development of a water quality index model for lakes and reservoirs. Paddy Water Environ. 12, S19, 2014

52. LING T.-Y., SOO C.-L., LIEW J.-J., NYANTI L., SIM S.-F., GRINANG J. Influence of Rainfall on the Physicochemical Characteristics of a Tropical River in Sarawak, Malaysia. Polish Journal of Environmental Studies, 26 (5), 2053, 2017. doi:10.15244/pjoes/69439

53. CALDERON M.S., AN K.G. Spatio-temporal variabilities of nutrients and chlorophyll, and the trophic state index deviations on the relation of nutrients-chlorophyll-light availability. Journal of Ecology and Environment. 39 (1), 31, 2016. doi:10.5141/ecoenv.2016.004

54. DIETER D., HERZOG C., HUPFER M. Effects of drying on phosphorus uptake in reflooded lake sediments. Environ. Sci. Pollut. Res. 22, 17065, 2015.

55. LEE C., LEE Y., CHIANG H. Abrupt state change of river water quality (turbidity): Effect of extreme rainfalls and typhoons. Sci. Total Environ. 91, 557, 2016.

56. KIM J.Y., AN K.G. Integrated Ecological River Health Assessments, Based on Water Chemistry, Physical Habitat Quality and Biological Integrity. Water. 7, 6378, 2015. doi:10.3390/w7116378.

57. MARKOGIANNI V., VARKITZI I., PAGOU K., PAVLIDOU A., DIMITRIOU E. Nutrient flows and related impacts between a Mediterranean river and the associated coastal area. Cont. Shelf Res. 134, 1, 2017.

58. NAPIÓRKOWSKA-KRZEBIETKE A., STAWECHI K., PYKA J.P., HUTOROWICZ J., ZDANOWSKI B. Phytoplankton in relation to water quality of a mesotrophic lake. Polish Journal of Environmental Studies, 22 (3), 793, 2013.

59. HAN J.H., AN K.G. Chemical Water Quality and Fish Community Characteristics in the Mid- to Downstream Reach of Geum River. Korean J. Environ. Biol. 31, 180, 2013.

60. CHOI J.W., HAN J.H., PARK C.S., KO D.G., KANG H.I., KIM J.Y., YUN Y.J., KWON H.H. AN K.G. Nutrients and sestonic chlorophyll dynamics in Asian lotic ecosystems and ecological stream health in relation to land-use patterns and water chemistry. Ecol. Eng. 79, 15, 2015.

61. KANOWNIK W., POLICHT-LATAWIEC A. Changeability of oxygen and biogenic indices in waters flowing through areas under various anthropopressures. Pol. J. Environ. Stud. 24 (4), 1633, 2015.

62. YUE S., PILON P., CAVADIAS G. Power of the Mann \pm Kendall and Spearman s rho tests for detecting monotonic trends in hydrological series. Journal of Hydrology. 259, 254, 2002.

63. VIEIRA J.S., PIRES J.C., MARTINS F.G., VIIAR V.J., BOAVENTURA R.A., BOTEIHO C.M. Surface water quality assessment of Lis River using multivariate statistical methods. Water, Air, \& Soil Pollution, 223, 5549, 2012.

64. MUANGTHONG S., SHRESTHA S. Assessment of surface water quality using multivariate statistical techniques: case study of the Nampong River and Songkhram River, Thailand. Environmental Monitoring and Assessment, 187 (9), 548, 2015.

65. KOLZAU S., WIEDNER C., RÜCKER J., KÖHLER J., KÖHLER A., DOLMAN A.M. Seasonal patterns of Nitrogen and Phosphorus limitation in four German Lakes and the predictability of limitation status from ambient nutrient concentrations. PLoS ONE, 9 (4), 2014. doi:10.1371/journal.pone. 0096065

66. ÖZDEMIR Ö. Application of multivariate statistical methods for water quality assessment of KarasuSarmisakli Creeks and Kizilirmak River in Kayseri, Turkey. Polish Journal of Environmental Studies, 25 (3), 1149, 2016.

67. HOLBACH, A., WANG, L.J., CHEN, H., HU, W., SCHLEICHER, N., ZHENG, B., NORRA S. Water mass interaction in the confluence zone of the Daning River and the Yangtze River- a driving force for algal growth in the Three Gorges Reservoir. Environ. Sci. Pollut. Res. 20, 7027, 2013. http://dx.doi.org/10.1007/s11356-012-1373-3

68. PAIÁCIO S.M., ESPINOZA-QUIÑONES F.R.E., DE PAUII A.R., QUEIROZ C.B., FABRIS S.C., FAGUNDESKIEN M.R., VEIT M., PIANA P.A. Assessment of anthropogenic impacts on the water quality of Marreco River, Brazil, based on principal component analysis and toxicological assays. Water Air Soil Pollution, 227, 307, 2016. https://doi.org/10.1007/s11270-016-3025-6

69. SAFFRAN K., CASH K., HALLARD K. Canadian water quality guidelines for the protection of aquatic life. CCME water quality Index, 1, 200, 2001.

70. RAMOS T.B., GONÇALVES M.C., BRANCO M.A., BRITO D., RODRIGUES S., SÁNCHEZ-PÉREZ J.M., SAUVAGE S., PRAZERES Â., MARTINS J.C., FERNANDES M.L., PIRES F.P. Sediment and nutrient dynamics during storm events in the Enxoé temporary river, southern Portugal. Catena. 127, 177, 2015.

71. YAN H., HUANG Y., WANG G., ZHANG X., SHANG M., FENG L., DONG J., SHAN K., WU D., ZHOU B., YUAN Y. Water eutrophication evaluation based on rough set and petri nets A case study in Xiangxi-River. Three Gorges Reservoir. Ecol. Indic. 69, 463, 2016.

72. WU Y.H., WANG X.X., ZHOU J., BING H.J., SUN H.Y., WANG J.P. The fate of phosphorus in sediments after the full operation of the Three Gorges Reservoir, China. Environ. Pollut. 214, 282, 2016. http://dx.doi.org/10.1016/j. envpol.2016.04.029.

73. MAMUN M., AN K. G. Major nutrients and chlorophyll dynamics in Korean agricultural reservoirs along with an analysis of trophic state index deviation. Journal of Asia-Pacific Biodiversity, 10 (2), 183, 2017. doi:10.1016/j. japb.2017.04.001

74. AN K.G., JONES J.R. Temporal and spatial patterns in ionic salinity and suspended solids in a reservoir influenced by the Asian monsoon. Hydrobiologia. 436, $179, \mathbf{2 0 0 0}$

75. CAO Z.J., ZHANG X.B., AI N.S. Effect of sediment on concentration of dissolved phosphorus in the Three Gorges Reservoir. Int. J. Sediment Res. 26, 87, 2011. http://dx.doi. org/10.1016/S1001-6279(11)60078-4.

76. HUANG Y., ZHANG P., LIU D., YANG Z.J., JI D. Nutrient spatial pattern of the upstream, mainstream and tributaries of the Three Gorges Reservoir in China. Environ. Monit. Assess. 186, 6833, 2014.

77. YANG B., JIANG Y., HE W., LIU W., KONG X., JORGENSEN S.E., XU F. The tempo- spatial variations of phytoplankton diversities and their correlation with trophic state levels levels in a large eutrophic Chinese lake. Ecol. Indic. 66, 153, 2016.

78. DOLMAN A.M., RUCKER J., PICK F.R., FASTNER J., ROHRLACK T., MISCHKE U., WIEDNER C. Cyanobacteria and cyanotoxins: The influence of nitrogen versus phosphorus. PLoS ONE, 7 (6), e38757, 2012. doi:10.1371/journal.pone.0038757 
79. AYDIN-UNCUMUSAOĞLU A., AKKAN T. Assessment of Stream Water Quality Using Multivariate Statistical Techniques. Polish Journal of Environmental Studies, 26 (4), 1715, 2017. doi:10.15244/pjoes/68952
80. XIA Y., TI C., SHE D., YAN X. Linking river nutrient concentrations to land use and rainfall in a paddy agriculture- urban area gradient watershed in southeast China. Sci. Total Environ. 1094, 566, 2016. 
